\title{
A TERCEIRA DÉCADA DIXITAL
}

Francisco Campos Freire

Universidade de Santiago de Compostela

Doi:10.17075/aceg.2016.001 

Dicimos terceira pero, en realidade, pode ser cuarta ou quinta porque o proceso de converxencia dixital se remonta aos últimos vinte anos do pasado século xx se botamos o ollo á xenealoxía da sociedade da información. Pero a idea do titular non é mirar cara a atrás, senón pensar a futuro, é dicir, na próxima terceira década do século XXI. O obxectivo deste traballo é pasar revista á situación actual da estrutura da industria cultural e das políticas institucionais coa perspectiva posta na próxima década que se aveciña. Unha revisión que inevitablemente hai que enmarcar nunha transición dixital que avanza máis rápido que a capacidade de xestión e reacción que teñen as políticas institucionais e as principais empresas tradicionais da prensa, radiotelevisión, audiovisual e produción editorial.

A converxencia dixital é un proceso da sociedade contemporánea que se remonta á orixe das industrias modernas da comunicación (telégrafo, teléfono e audiovisual) ao aproximar tecnoloxías eléctricas e mecánicas e que ten a súa eclosión (Flichy 1982) na confluencia das chamadas novas tecnoloxías da información (informática e telecomunicacións).

Aínda que a noción da converxencia se remonta aos séculos XVIII e XIX (William Derham e Charles Darwin xa a empregaron) e logo ao tránsito da sociedade postindustrial á da información (Brzezinski chámalle tecnotrónica e Negroponte ou John Sculley convértena en tecnoutopía), a dixitalización (que é a tradución da información a díxitos en expresión orixinal básica de Pierre Lévy 2007: 36-37) dálle un novo sentido permitindo a súa compresión, integración multimedia e transmisión.

A converxencia dixital, que se estudou e definiu logo máis amplamente (Jenkins 2006), é unha cultura e un conxunto de procesos de transformación tecnolóxica, económica, organizativa e social que afectan os usuarios (consumidores e audiencias) e os fluxos de información e comunicación así como a case todas as industrias e, especialmente, as culturais. Outro efecto da converxencia é a ruptura da relación física dos contidos cos seus soportes analóxicos, convertendo os produtos en servizos intanxibles, desmaterializando o soporte de lexitimación da transación intelectual e provocando a ruptura dos modelos tradicionais de negocio das industrias culturais.

A revolución dixital transcendeu os ámbitos tecnolóxicos e non só se converteu en interface disruptiva da economía e das industrias tradicionais da cultura, senón tamén nunha especie de paradigma do home novo biotecnolóxico, conectado e prosumer, que Pierre Calmard (2015) retrata no seu ensaio L'homme à venir. Comment le numérique va nous transformer. Polo tanto, a converxencia tecnolóxica non só está afectando os dispositivos que nos rodean, senón tamén as nosas propias vidas.

A revolución da última década do século xx foi a da web (a comunicación a través de Internet), a dos primeiros dez anos do XXı foi a da autocomunicación (a da web social 2.0 e as redes dixitais), a da segunda década é a da Internet das cousas (automatización das comunicacións e da web semántica 3.0) e a da terceira vai ser a da intelixencia artificial (a comunicación intelixente das máquinas, a web 4.0, cos homes).

A biotecnoloxía aspira liberar a mente humana do sobrealmacenamento de datos para poder ampliar a súa capacidade de atención, reacción e multitarefa das persoas. Por iso, Google contrataba en 2012 como director de enxeñaría o científico Ray Kurzweil, experto en comunicación home-máquina. Coa biotecnoloxía «nada impide a creación de novos xéneros, novas formas de representación da especie e da plurisexualidade», segundo imaxina Pierre Calmard (2015) no seu futurista ensaio sobre a revolución dixital. 
Fronte a esas prospectivas futuristas da biotecnoloxía, da apropiación máis intensiva do cerebro e do corpo humano por parte da industria, os cambios no mundo das comunicacións e das plataformas mediáticas xa son reais e actuais. Google, Apple, Facebook ou Amazon son tres veces máis poderosas e teñen maiores ganancias que a empresa de comunicación tradicional máis grande do mundo.

Os medios de comunicación tradicionais, a escala global ou local, enfróntanse a moitos retos ao mesmo tempo: perda de control sobre os seus sistemas de distribución; sobre os seus modelos de negocio e monetización; sobre a capacidade de ser gardiáns editoriais, de reputación e credibilidade; sobre a converxencia, hibridación e confusión da información coa publicidade; sobre a lexitimidade da opinión pública e a súa sustentabilidade; e sobre a adaptación a un proceso radical de novas formas de economía da atención, da afiliación, da pescuda da pegada dixital, da recomendación e colaboración, como describe Michel Bauwens na súa recente obra Sauver le monde, vers une économie post-capitaliste avec le peer-to-peer (2015), que prologa Bernard Stiegler sentenciando que «non vivimos nunha época de cambios, senón nun cambio de época».

A reacción dos medios tradicionais fronte á disrupción da economía dixital é de desconcerto, incerteza e axuste económico para compensar a perda de ingresos que rexistran os seus modelos de negocio da vella economía. 0 dilema non é fácil de resolver porque os modelos de negocio tradicionais están perdendo valor fronte aos da nova economía polo cambio no comportamento dos consumidores e pola alteración nos custos de transación. Debido á dificultade de asumir os cambios disruptivos, a alternativa para os medios tradicionais é a innovación adaptativa (Campos 2015) para a recuperación do valor e a compensación a medio prazo dos vellos e novos modelos de negocio.

A transición da economía analóxica á dixital é complexa pero é inevitable. E, ademais, estase producindo a maior velocidade da que precisan algunhas empresas e industrias para a súa adaptación. Aínda que non é o noso obxectivo facer predicións agoireiras, as análises de tendencias dos tres principais sectores da industria da comunicación -a prensa, o audiovisual e a publicidade- delimitan unha década (2015-2025) de radical transformación. Máis adiante reproducimos datos, estatísticas e gráficas.

\section{A TRANSICIÓN DIXITAL}

As previsións sobre a industria dos medios de comunicación e o entretemento que ofrecen os informes de prospectiva de 2015-2019 de PWC (PricewaterhouseCoopers 2015) e Global Digital Media da Asociación Mundial de Diarios (WNMN 2014) son coincidentes en que o crecemento deste hipersector estará protagonizado nos próximos anos polos servizos dixitais mentres os negocios tradicionais da edición, impresión, audiovisual e publicidade rexistran perdas continuadas nas súas evolucións. Ao resumo dos datos destes informes, seguirán as cifras da nosa pescuda sobre a situación dos medios en Europa, España e Galicia, que tamén son coincidentes coas tendencias de carácter xeral.

A difusión da prensa impresa nos últimos cinco anos foi claramente á baixa, especialmente en Europa, cun descenso xeral situado arredor do 20 \% da súa circulación, como dan conta as cifras ponderadas do informe de 2014 de World Trends da Asociación Mundial de Diarios (WAN-IFRA). Dicimos ponderadas porque as porcentaxes comparativas de 2013 fronte a 2009 só son con respecto a aqueles países dos que hai datos de ambos os anos. E o investimento publicitario é lineal, sen repercusión da inflación. 
Cadro 1. Evolución mundial da prensa impresa

\begin{tabular}{lrrrrrrr} 
Continentes & $\mathbf{2 0 0 8}$ & $\mathbf{2 0 0 9}$ & $\mathbf{2 0 1 0}$ & $\mathbf{2 0 1 1}$ & $\mathbf{2 0 1 2}$ & $\mathbf{2 0 1 3}$ & 2013-2009 \\
\hline África & 9065 & 9581 & 10110 & 12805 & 5583 & 1346 & $-22,34 \%$ \\
\hline Asia & 316981 & 342649 & 344000 & 333945 & 333338 & 66640 & $-0,04$ \\
\hline América & 81722 & 78504 & 76179 & 75258 & 72606 & 15513 & $-1,53$ \\
\hline Europa & 129791 & 117501 & 105956 & 99710 & 91600 & 78640 & $-23,59$ \\
\hline Mundo & 537762 & 548867 & 536880 & 520338 & 504107 & 162139 & $-17,45$ \\
\hline \multicolumn{7}{c}{ Número de cabeceiras } \\
\hline África & 178 & 186 & 185 & 185 & 21 & 21 & 5 \\
\hline Asia & 5626 & 5834 & 5968 & 7336 & 6539 & 708 & 3,82 \\
\hline América & 3240 & 3148 & 3136 & 3136 & 3206 & 2327 & 6,37 \\
\hline Europa & 2383 & 2365 & 2292 & 2296 & 2146 & 1524 & $-10,49$ \\
\hline Mundo & 11427 & 11533 & 11582 & 12926 & 11912 & 4580 & $-5,13$ \\
\hline \multicolumn{7}{c}{ Investimento publicitario } \\
\hline África & 3500 & 3650 & 4220 & 4400 & 4682 & 4381 & 20,02 \\
\hline Asia & 113757 & 114310 & 127825 & 135796 & 140765 & 137414 & 20,21 \\
\hline América & 170210 & 177902 & 186844 & 193329 & 203451 & 212567 & 19,48 \\
\hline Europa & 115785 & 116260 & 122468 & 126294 & 122819 & 121293 & 4,32 \\
\hline Mundo & 403252 & 412123 & 441359 & 459820 & 471718 & 475656 & 15,41 \\
\hline
\end{tabular}

Fonte: elaboración propia con cifras de World Trends WAN-IFRA, 2014. Os datos de difusión son en millóns de exemplares e os de investimento publicitario en millóns de dólares. Os datos de 2013 non están completos na base de WAN-IFRA e por iso a evolución porcentual só se refire á comparación dos países e anos dos que hai cifras homoxéneas. En Asia agréganse os datos de Australia, Oceanía, Turquía e Emiratos Árabes.

Para os próximos cinco anos a previsión de ingresos da prensa segue sendo negativa, cun descenso porcentual situado entre o -0,9 e o-0,7 a partir de 2017, segundo as estimacións de PWC.

Eses descensos afectan tanto os ingresos pola venda de exemplares como por publicidade, a pesar de que aumentará lixeiramente a circulación (de 552,7 millóns de copias en 2014 a 580,7 millóns en 2019), pero a prezos máis reducidos nos mercados dos países emerxentes. China e India, como expresión da alfabetización e das novas economías de consumo, son os países que protagonizarán en 2019 o crecemento e o 57,3% da circulación mundial da prensa.

Outra significativa tendencia é a converxencia das porcentaxes de ingresos por publicidade e circulación, que se ben as primeiras eran maiores (o 54,4 \%) que as segundas en 2010, para o ano 2019 estímase que se igualarán arredor do $50 \%$. Os ingresos pola subscrición dixital (paywall, muro de pago) non compensan aínda os descensos da publicidade e da circulación do sistema tradicional impreso. Estímanse eses ingresos dixitais nunha media de entre o 8 \% e o 12 \% (Picard 2014) da facturación xeral dos xornais, equivalente aínda a un negocio de troco de dólares analóxicos por centavos dixitais (como afirma Mathew Ingram). A monetización dos accesos e transaccións a través do móbil é outra parte do desafío porque a partir de 2017 máis da metade da poboación mundial estará conectada á Internet de mobilidade.

Hai varios estudos e predicións sobre a evolución da prensa en papel. O máis recente con respecto á elaboración deste traballo é un informe -publicado en agosto de 2015- de Ken Goldstein, analista dos negocios de comunicación, acerca da evolución da prensa en Canadá, que rexistra unha caída da súa circulación de pago en máis do 
Cadro 2. Proxección mundial dos ingresos da prensa
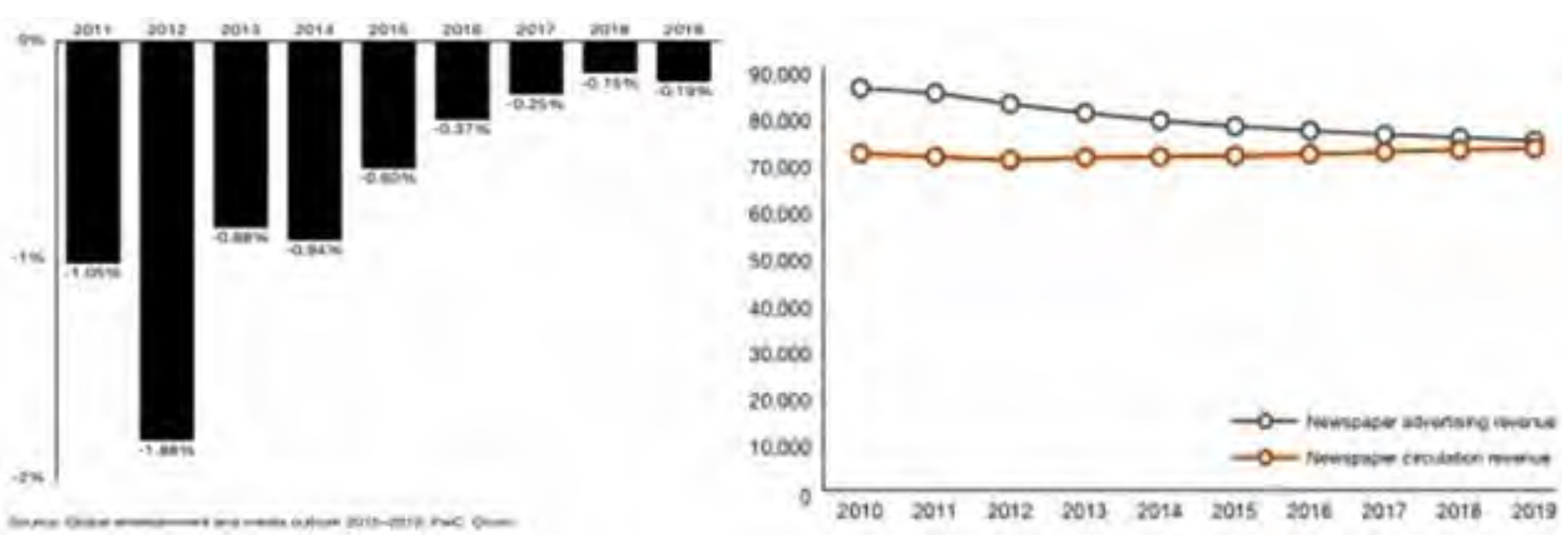

Fonte: PWC 2015. Evolución porcentual dos ingresos da prensa e converxencia das vendas por circulación e publicidade.

20 por cento entre 1995 e 2014 e proxecta a mesma continuidade do desprazamento ata 2025, ano para o que prevé apenas entre un 5 e un 10 por cento de fogares canadenses con xornais impresos, mentres que hai 20 anos esa taxa era dez veces superior. Este analista conclúe que as empresas xornalísticas teñen dez anos por diante para adaptar os seus negocios de información aos modelos de negocio dixitais.

Cadro 3. Proxección da prensa de Canadá, 1995-25
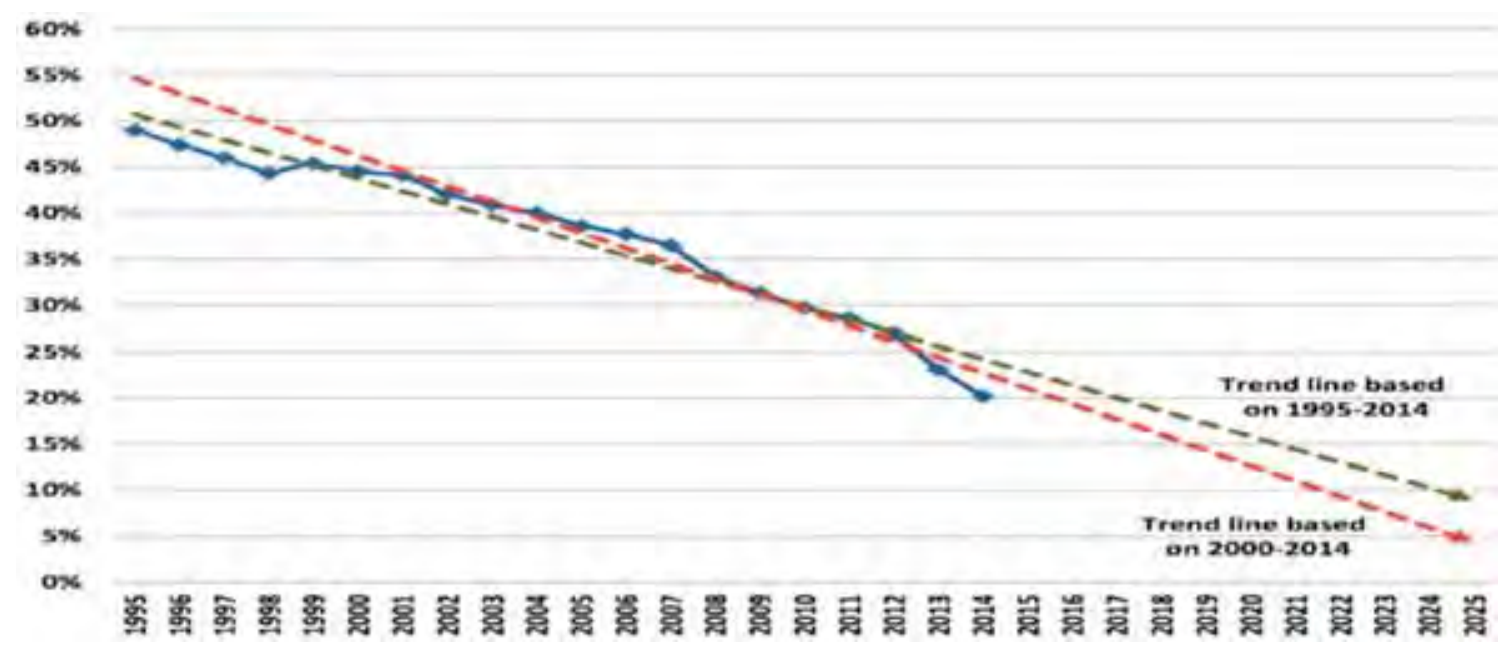

O comportamento global da migración na industria do libro en papel é semellante ao da prensa, manténdose nos países de alfabetización recente e adaptándose aos ecosistemas dixitais no resto do mundo occidental, aínda que con conxunturais fluxos e refluxos, coma no caso de España en 2014 (medrou a impresión fronte ao dixital). A da música foi a primeira que sufriu a transformación. Se a crise das industrias da impresión (nos soportes de papel e vinilo) empeza a notarse na última década do século xx, a da televisión convencional chega dez anos máis tarde coa emerxencia de diversas formas de acceso e consumo do audiovisual mediante descargas (streaming) e novos dispositivos móbiles. O consumo da televisión en liña e en vivo, baseado na programación e no soporte da publicidade como sistema de financiamento, empeza a trocarse por novas formas de acceso e sistema multicanle, sobre todo nas franxas de idades por debaixo dos 35 anos. 
Cadro 4. Trocos no consumo da TV tradicional
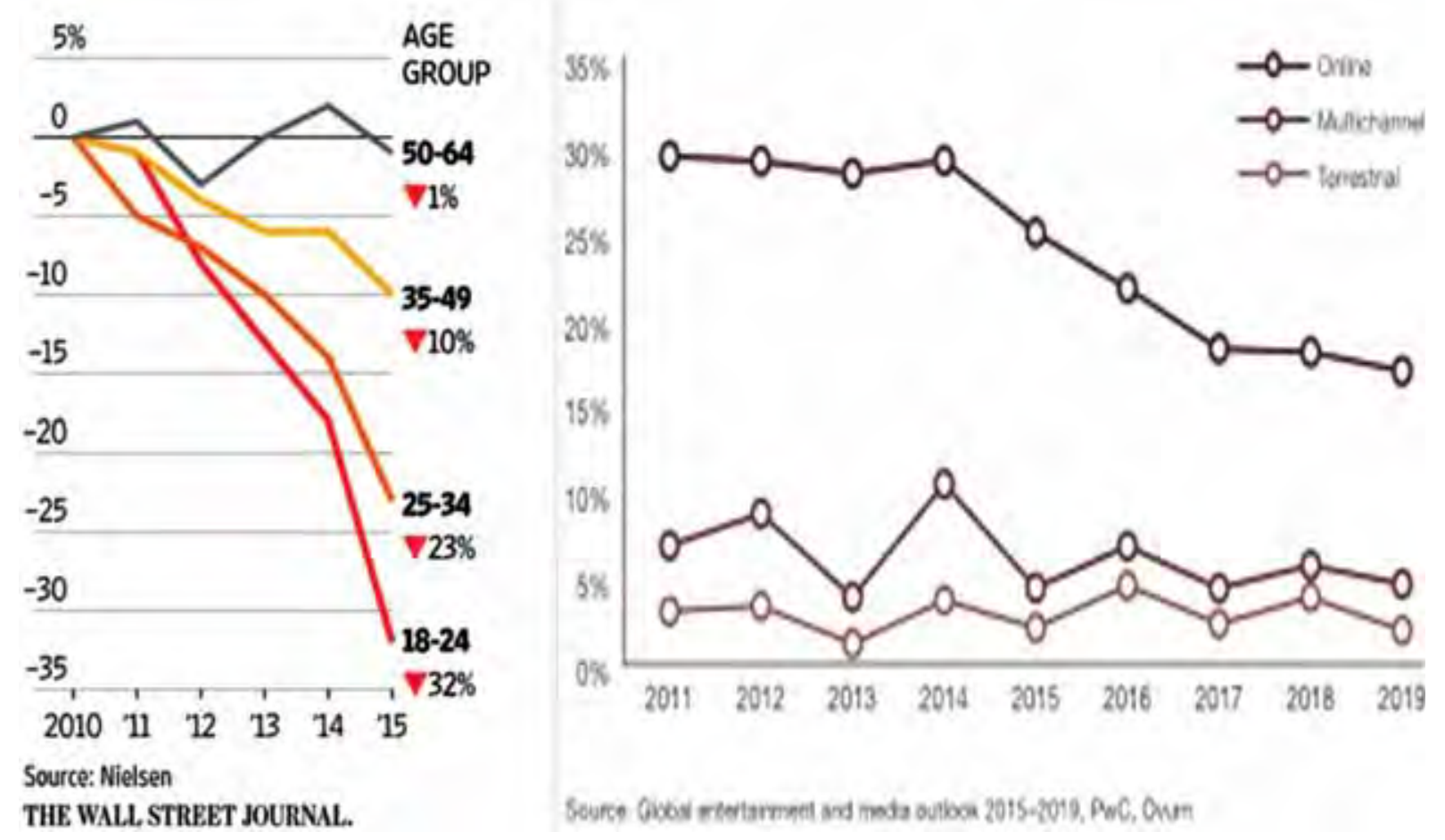

Fontes: De Nielsen-The Wall Street Journal e Global Entertainment and Media Outlook 2015-19 de PWC.

As previsións de ingresos por publicidade na televisión convencional son de clara desaceleración (un 2,8 \% de crecemento na terrestre e un 5,1\% na multicanle) mentres que para o audiovisual en liña o informe de PWC 2015 rexistra un incremento do $20 \%$ a cinco anos vista.

De feito, en Europa, con relación á difusión da TV por ondas hertzianas, que culminou o seu apagamento analóxico en 2014, xa se fala de que entre 2025 e 2030 habería que producir o apagado definitivo da televisión dixital terrestre para liberar as súas radiofrecuencias para a telefonía móbil e Internet (banda 470-694 Mhz). Esta proposta de supresión total da TDT foi levada á Conferencia Mundial de Radiofrecuencias de 2015 e rexeitada polos operadores tradicionais de televisión, que recorreron a informes de Pascual Lamy e de impacto económico negativo por máis de 38500 millóns de euros. 0 tema é dramático para a televisión en aberto e, sobre todo, para a radiotelevisión pública, que, cada vez que se produce un apagamento tecnolóxico, perde máis peso e forza.

A versatilidade dos diversos equipos e redes de acceso está cambiando radicalmente os usos do audiovisual, descargando e elaborando menús personalizados a medida dos distintos gustos e tempos de consumo dispoñibles, sen necesidade de estar pendentes da programación horaria en liña nin sometidos á atención dos anuncios publicitarios. Un estudo de Ericson (2015) revela, baseándose nunha enquisa realizada nos 20 principais mercados mundiais, que os espectadores durante a emisión da publicidade deciden, pola seguinte orde, cambiar de canle para ver outros programas; deixar de prestar atención á pantalla para facer outra cousa; navegar por Internet coa computadora ou co teléfono intelixente; interactuar nos medios sociais; usar un bloqueador de publicidade; buscar servizos sen publicidade; ou gravar contidos para descárgalos logo en streaming noutro momento.

Estas novas formas de uso e consumo cambian o concepto orixinal de televisión (broadcasting) por outro máis amplo de audiovisual e, polo tanto, tamén os seus modelos de negocio. Os servizos audiovisuais a través de Internet ofrecen novas experiencias para os consumidores consonte a súa flexibilidade (consumir o que se quere e cando se quere), contidos exclusivos personalizados e de maior calidade. Este auxe dos servizos de vídeo (over-the-top, 
OTT) está cambiando pouco a pouco as formas da publicidade. As previsións de ingresos de PWC 2015 sobre a publicidade na televisión xeralista, que ata agora era un investimento maioritario, reflicten unha caída do $5 \%$ para os próximos cinco anos, aínda que se manterán arredor do $90 \%$.

Nas enquisas, os consumidores comprenden que a publicidade é un sistema de financiamento necesario para a produción de contidos pero rexeitan a saturación e a intrusión desta (Ericson 2015). Valoran máis favorablemente a inclusión da publicidade ao comezo ou ao final das reproducións -porque a poden saltar- que a intrusión dela no medio dos contidos. Por iso a chamada publicidade nativa de colocación de produto (encaixada dentro dos contidos) e os servizos coma YouTube, Netflix, Amazon ou Hulu están a cobrar grande importancia nos modelos de distribución e negocio do audiovisual. Eses modelos están orientando tamén a publicidade cara ao patrocinio, bartering, márketing data, xeolocalización e personalización dos receptores.

O impacto económico global deses novos operadores dixitais detectouse rechamantemente a mediados de agosto de 2015 nas cotizacións dos principais grupos de medios audiovisuais (Disney, 21st Century Fox, Time Warner ou Viacom) do Index 500 de Standard \& Poor's de Nova York, no que en dous días perderon máis de mil millóns de capitalización -a caída máis forte desde 2008- ao revelarse as baixas nas subscricións da televisión de pago (principalmente da canle ESPN dos grandes acontecementos deportivos) fronte ao ascenso espectacular de Netflix, que xa ten 41 millóns de afiliados en Estados Unidos e unha valoración bolsista de 54000 millóns de dólares, case ao mesmo nivel que a Fox de Rupert Murdoch.

O modelo Netflix está comezando a atacar igualmente as marxes de negocio dos operadores europeos. En Francia xa acada unha cota do $10 \%$ do mercado. Tanto que as empresas tradicionais reaccionan con ofertas semellantes (BBC) e alianzas a distintas bandas (NBC/Universal/Concast buscando a Vox Media e BuzzFed, Facebook creando Live ou Fox Sports xuntándose con YouTube) para non perder a carreira da innovación.

Outra estratexia reactiva é a concentración dos grupos mediáticos. As 50 maiores empresas do mundo neste sector facturan máis de 400000 millóns de dólares, o 66,49 \% dese importe (264 131 millóns) é de Estados Unidos, o 17,2 \% (68 500 millóns) de Europa, o 12,5 \% (49 798 millóns) de Xapón e o 17,2% (15 112 millóns) doutros países. E dos 50 principais grupos audiovisuais presentes en Europa, 27 son de EE.UU. (máis do 50 \%), 6 de Xapón, 4 de Alemaña, 3 do Reino Unido, 2 de Francia, 2 de Italia, 1 de Brasil e outro de México (OBS 2014).

O panorama audiovisual europeo de 2008 a 2012, período do que se dispón de datos comparativos homoxéneos, apuntaba as tendencias que agora se están a revelar, coa excepción de que nese intre aínda non se apreciaba o impacto na televisión de pago tradicional dos novos servizos dixitais, que porén xa despuntaban con altas porcentaxes de crecemento; e como tamén o facía o vídeo baixo demanda. A industria audiovisual europea (incluíndo os videoxogos) reporta arredor de 135000 millóns de euros e 640000 empregos por parte de 122755 empresas. A televisión tradicional xera preto de 75000 millóns de euros; a televisión de pago, 35000 millóns, e o cine, case 7000 millóns.

Cadro 5. Panorama audiovisual europeo

\begin{tabular}{lrrrrrrr} 
Operadores & $\mathbf{2 0 0 8}$ & $\mathbf{2 0 0 9}$ & $\mathbf{2 0 1 0}$ & $\mathbf{2 0 1 1}$ & $\mathbf{2 0 1 2}$ & $\mathbf{2 0 1 2 - 2 0 1 1}$ & $\mathbf{2 0 1 2 - 2 0 0 8}$ \\
\hline \multicolumn{7}{c}{ Relevisión en aberto } \\
\hline RTV públicas & 32370 & 33434 & 33815 & 33687 & 32626 & $-3,1 \%$ & $0,7 \%$ \\
\hline Publicidade TV & 21664 & 20096 & 21139 & 21941 & 21057 & $-4,0$ & $-2,8$ \\
\hline TV temática & 9021 & 9791 & 10859 & 12334 & 12578 & 2,0 & 39,43 \\
\hline Televenda & 2442 & 2423 & 2577 & 2719 & 2800 & 3,0 & 14,66 \\
\hline TV local & 1607 & 1555 & 1573 & 1496 & 1423 & $-4,9$ & $-11,44$ \\
\hline Radio privada & 4167 & 3893 & 4040 & 4168 & 4115 & $-1,3$ & $-1,24$ \\
\hline Total TV & 71270 & 71192 & 74002 & 76345 & 74599 & $-2,3$ & 4,67 \\
\hline
\end{tabular}




\begin{tabular}{|c|c|c|c|c|c|c|c|}
\hline Operadores & 2008 & 2009 & 2010 & 2011 & 2012 & 2012-2011 & 2012-2008 \\
\hline \multicolumn{8}{|c|}{ Ingresos da TV de pago } \\
\hline Cable & 11201 & 11314 & 12050 & 12328 & 12952 & 5,0 & 15,63 \\
\hline Satélite & 13255 & 13298 & 14954 & 15470 & 16219 & 4,8 & 22,36 \\
\hline IPTV & 1395 & 2042 & 2899 & 3343 & 4168 & 24,7 & 198,78 \\
\hline DTT & 598 & 954 & 1439 & 1525 & 1613 & 5,8 & 169,73 \\
\hline Total & 26448 & 27609 & 31342 & 32677 & 34952 & 7,0 & 32,15 \\
\hline \multicolumn{8}{|c|}{ Cine e vídeo } \\
\hline Recadación cine & 5626 & 6087 & 6373 & 6445 & 6570 & 1,9 & 16,77 \\
\hline DVD venda & 7727 & 6729 & 6198 & 5532 & 4913 & $-11,2$ & $-36,41$ \\
\hline DVD alugueiro & 1372 & 1167 & 1037 & 900 & 763 & $-15,2$ & $-44,38$ \\
\hline Blu-ray venda & 234 & 500 & 807 & 982 & 1126 & 14,7 & 381,19 \\
\hline Bluray alugueiro & 16 & 42 & 84 & 116 & 163 & 41,3 & 918 \\
\hline Total vídeo & 9348 & 8438 & 8126 & 7530 & 6966 & $-7,55$ & $-25,48$ \\
\hline \multicolumn{8}{|c|}{ Ingresos do vídeo en liña } \\
\hline VOD TV & 97 & 161 & 298 & 392 & 575 & 46,6 & 482,78 \\
\hline VOD cine & 26,8 & 59,0 & 117,2 & 189,2 & 380,9 & $10,1,3$ & 132,12 \\
\hline VOD total & 124 & 220 & 415 & 582 & 596 & 64,4 & 380,64 \\
\hline Videoxogos & 10848 & 10683 & 11061 & 11150 & 10886 & $-2,4$ & 0,35 \\
\hline Total audiovis. & 123664 & 124230 & 131318 & 134729 & 134929 & 0,1 & 9,10 \\
\hline \multicolumn{8}{|c|}{ Empresas audiovisuais europeas, ingresos e emprego } \\
\hline$\overline{N^{\circ}}$ empr. AV & & 110151 & 122165 & 122755 & & 11,4 & 11,44 \\
\hline Ingresos & & 126639 & 130768 & 131239 & & 0,4 & 3,63 \\
\hline Emprego & & 648053 & 643603 & 639450 & & $-0,6$ & $-1,32$ \\
\hline
\end{tabular}

Fonte: elaboración propia con datos de ingresos en millóns de euros do European Audiovisual Observatory (OBS 2014). No apartado de empresas e emprego, os datos refírense ás comparacións dos anos 2011-2010 e 2009, respectivamente.

A taxa de crecemento da televisión de pago, pola saturación de ofertas e a entrada dos novos operadores, tamén está trastornándose e desacelerándose, sobre todo en América do Norte e Europa Occidental, baixou dun 5,3\% de incremento entre 2010 e 2014 a un 3,4 \% de 2015 a 2019, segundo o informe de PWC. A batalla está agora na conformación das ofertas, prezos e economías de escala coas que se teñen que enfrontar os vellos e novos operadores. As microofertas multiflexibles por 9 dólares ao mes dos novos operadores (Netflix ou Amazon) rompen os prezos e as programacións das plataformas tradicionais de pago.

A flexibilidade desas novas plataformas de distribución de contidos a través de Internet -con capacidade e custos de estrutura moitísimo máis baixos que as redes terrestres, de cable ou satélite- permiten amplas e variadas ofertas de contidos que impulsan a industria cinematográfica e tamén oportunidades para os creadores independentes. Non obstante, esas plataformas están empezando, pola súa vez, a introducirse na produción de series e películas para nutrir os seus catálogos.

Esa demanda xunto cos novos dispositivos de acceso móbil (tabletas e teléfonos) e cos mercados emerxentes de Asia e América Latina fortalecen as previsións de recuperación da industria cinematográfica, que se estima que medrará arredor do 4,1 \% anual ata 2019. O mesmo ocorre coa produción de videoxogos, nos que tamén se está a dar o troco dos modelos analóxicos aos dixitais, ao xogo social, á distribución a través da nube e á irrupción da realidade virtual tanto para os espazos de entretemento como para os de información xornalística e formación educativa. 
A análise da evolución dos ingresos e resultados dos grandes grupos audiovisuais privados europeos confirma de igual maneira as tendencias que se veñen comentando. Aínda que cada un deles é o resultado dunha estrutura económico-financeira diferente, a partir de 2011-12 pódese apreciar unha clara contención nos ingresos e resultados froito da apertura do punto de inflexión online do negocio tradicional do audiovisual.

Cadro 6. Resultados dos grandes grupos audiovisuais da UE

\begin{tabular}{|c|c|c|c|c|c|c|c|c|}
\hline Grupos e país matriz & & 2008 & 2009 & 2010 & 2011 & 2012 & 2013 & 2014 \\
\hline \multirow{2}{*}{$\overline{\text { RTL Luxemburgo }}$} & Ingresos & 5774 & 5410 & 5591 & 5765 & 5998 & 5889 & 5808 \\
\hline & Resultados & 296 & 298 & 730 & 795 & 690 & 948 & 714 \\
\hline \multirow[t]{2}{*}{ BSKyBReino Unido } & Ingresos & 6250 & 7293 & 7772 & 8980 & 9244 & 9846 & 10386 \\
\hline & Resultados & -173 & 352 & 1185 & 1102 & 1232 & 1331 & 1174 \\
\hline \multirow[t]{2}{*}{ Canal + Francia } & Ingresos & 1813 & 1775 & 1787 & 1846 & 1878 & 1882 & 1830 \\
\hline & Resultados & 56 & 57 & 59 & 60 & 62 & 63 & 63 \\
\hline \multirow[t]{2}{*}{ TF1Francia } & Ingresos & 2594 & 2364 & 2622 & 2619 & 2215 & 2085 & 2091 \\
\hline & Resultados & 176 & 101 & 313 & 282 & 153 & 146 & 116 \\
\hline \multirow[t]{2}{*}{ PRISAEspaña } & Ingresos & 994 & 902 & 977 & 1138 & 1333 & 1546 & \\
\hline & Resultados & -269 & -676 & -407 & -277 & -195 & -133 & \\
\hline \multirow[t]{2}{*}{ Modern TimesSuecia } & Ingresos & 1385 & 1486 & 1378 & 1417 & 1403 & 1486 & \\
\hline & Resultados & 308 & 308 & 372 & -135 & 168 & 123 & \\
\hline \multirow[t]{2}{*}{ Prosieben SatAlemaña } & Ingresos & 3054 & 2760 & 2601 & 2199 & 2356 & 2605 & 2875 \\
\hline & Resultados & 125 & 150 & 346 & 312 & 295 & 637 & 312 \\
\hline \multirow[t]{2}{*}{ MediasetItalia } & Ingresos & 3271 & 3228 & 3438 & 3241 & 2835 & 2588 & \\
\hline & Resultados & 272 & 272 & 352 & 225 & -287 & 8,9 & \\
\hline \multirow[t]{2}{*}{ CEMEBermudas } & Ingresos & 905 & 605 & 654 & 767 & 626 & 562 & 604 \\
\hline & Resultados & -226 & -95 & 85 & -159 & -484 & -249 & -205 \\
\hline \multirow[t]{2}{*}{ TVN-ITIPolonia } & Ingresos & 393 & 369 & 392 & 394 & 337 & 327 & 323 \\
\hline & Resultados & 95 & 98 & 65 & 266 & 7,1 & -40 & 26 \\
\hline
\end{tabular}

Fonte: elaboración propia con datos en millóns de euros, a partir dos resultados publicados polas respectivas empresas.

\section{MODELOS DE NEGOCIO E ESTRATEXIAS}

A industria mediática actual está experimentando unha acelerada transición dos modelos tradicionais físicos e analóxicos aos da economía dixital e intanxible. Pero o gran reto e desafío é como xestionar esa economía dixital para protexer dereitos básicos individuais e equilibrar a sustentabilidade de moitas organizacións imprescindibles para o mantemento do pluralismo e a diversidade.

A innovación disruptiva que introduciu Internet e a dixitalización abriron as comportas de novos modelos de negocio, de espazos desregulamentados, desprotección da propiedade intelectual e a privacidade, de novas economías da colaboración, da gratuidade, do troco e da pescuda do data márketing a partir das pegadas dixitais producidas pola navegación. Pero o paradoxo dalgunhas desas economías é a sobreexplotación da atención, a experiencia, as interacións, o procomún dos prosumer e a privacidade das individualidades porque, cando non se paga polo produto, o usuario é o produto. 
Os modelos de negocio representan as bases mediante as cales unha empresa ou organización crea, proporciona e capta valor para a súa clientela, socios, empregados, asociados e para a sociedade en xeral a partir dos seguintes elementos: mercados e clientes, propostas de valor dos produtos ou servizos, canles de distribución e comunicación, sistemas de relación cos clientes, fontes de ingresos e prezos, recursos e actividades clave, asociacións estratéxicas e estrutura e tipos de custos. Os principais modelos de negocio das industrias da comunicación, segundo os seus sistemas de transacción (Celaya 2014), pódense agrupar nas seguintes categorías:

1. De propiedade, financiamento e xestión pública (radiotelevisións): canon, subvención, convenios, préstamos financiados, bonificacións e/ou exencións fiscais.

2. De pago do produto: por unidade, paquete, subscrición e alugueiro.

3. De publicidade: acceso aberto ou libre, patrocinio, bartering, merchandising e product placement (colocación de produto/publicidade nativa).

4. De pago do servizo dixital audiovisual: triplo e múltiple play, pago por visión (PPV), por descarga, por paquete, subscrición e alugueiro de acceso a streaming.

5. De paywall de prensa: micropagos, paquete (blendle), muro fechado de pago total, freemium-premium; pago mediado; e membresía ou club.

6. De agregadores de multiservizos e plataformas de fidelización de clientes (ofrecer contidos gratis para gañar clientes para servizos de pago).

7. De márketing data: comercialización de datos dixitais de afiliación rexistrados polos usuarios nas plataformas e redes sociais.

8. De recomendación (economía do click) e reputación dixital de servizos.

9. De comunidades de filantropía, crowfunding e mecenado.

10. Doutras formas híbridas: P2P-MOOC'S, crowdsourcing ou gamificación.

Pero a converxencia dixital non só revoluciona os modos de consumo e modelos de negocio tradicionais, senón tamén as estruturas e formas de organización da creación, produción e xestión das empresas, que necesitan situar os consumidores moito máis no centro do seu corazón estratéxico para recuperar a súa confianza con rapidez, axilidade e innovación. Un reto enorme para moitas organizacións tradicionais e, sobre todo, en Europa para as da radiotelevisión pública -que abordaremos a continuación- que aínda permanecen ancoradas nas vellas estruturas burocratizadas e politizadas do século xx.

As principais barreiras, porén, coas que as empresas chocan para enfrontar o cambio -segundo o informe de Global Digital Media (WNMN 2014), realizado a partir dunha enquisa a 340 expertos en xestión de medios de comunicaciónson as seguintes: falta de talento nas áreas emerxentes das organizacións e na alta dirección delas, necesidades de capital e crédito para novos investimentos, conflitos de prioridades nas axendas internas (é dicir, como abandonar 0 pasado e presente febles, pero coñecidos, polo incerto futuro descoñecido), baixo nivel de investigación e innovación rigorosas, culturas obsoletas e necesidades de reestruturación, adaptación de novas métricas e ferramentas de xestión.

Nas prioridades que marcan os directivos da mostra mundial de medios de comunicación sobresaen as necesidades de reestruturación das organizacións, investimentos en tecnoloxía, desenvolver novos produtos, impulsar a creatividade e a innovación, racionalizar os sistemas e procesos produtivos, expansión nos mercados internos e externos, profundamento en sectores verticais, externalizar procesos de pouco valor engadido e cooperación para a sindicación de contidos. A necesidade convértese na matriz da innovación, tanto no ámbito organizacional coma no da creatividade de novos contidos e formatos, que converxen cara ao vídeo móbil, consumos non lineais e baixo demanda, busca de novas métricas e sistemas de monetización dos novos modelos de negocio. 


\section{O FUTURO DA RADIOTELEVISIÓN PÚBLICA}

O debate aberto no verán de 2015 sobre a próxima Carta Real da BBC (o documento estratéxico da corporación británica para 2017-2027) marca as tendencias de futuro da radiotelevisión pública en Europa. O Goberno conservador de David Cameron presentou diante do Parlamento do Reino Unido a BBC Charter Review Public Consultation (16 july-8 october 2015), que é a primeira consulta pública para elaborar a Carta Real da corporación de radiodifusión británica que deberá estar vixente o día 1 de xaneiro de 2017 e que marcará a estratexia para os dez anos seguintes, nos que precisamente esa corporación celebrará o seu centenario (2022).

Sen considerar que o modelo xeral europeo de radiotelevisión pública é equiparable á corporación británica, o seu debate e definición serven de referencia para outros países. A clasificación dos distintos modelos europeos de radiotelevisión pública pódese establecer sobre cinco grandes criterios: a) segundo o modelo de sistemas mediáticos comparados (Hallin / Mancini 2008); b) segundo o sistema de financiamento; c) segundo a súa configuración da organización institucional e territorial; d) segundo o seu sistema de gobernanza e control; e) segundo a súa penetración e audiencias fronte á competencia privada. A partir deses cinco grandes criterios pódense formular dez modelos diferenciais:

1. Modelos de sistemas mediáticos comparados: a) liberal (BBC do Reino Unido e RTE de Irlanda); b) corporativo-democrático (países do norte: Finlandia, Suecia, Alemaña, Noruega); c) pluralista partidista (países mediterráneos: Francia, Italia, España, Grecia, Portugal).

2. Modelos financiados maioritariamente a través de taxas impositivas: a) de canon directo sobre fogares (BBC, RTE, RTBF, VRT, ERT, ORF, ARD, ZDF, RAI, France TV); b) canon directo persoal (que se tributa a través da declaración do imposto da renda das persoas físicas, YLE de Finlandia); e c) canon indirecto (a través de operadores de telecomunicacións e televisión comerciais, RTVE e France TV).

3. Modelos de financiamento mixto de publicidade, canon e/ou subvención: radiotelevisións autonómicas de España, Alemaña, Bélxica, Países Baixos, Portugal, Italia e Irlanda.

4. Modelo único de diversidade institucional independente (países nórdicos e Suíza) mediante organización federal de canles rexionais integradas.

5. Modelo estatal confederado (España e Alemaña) a través dunha organización estatal (RTVE e ZDF) e outra de corporacións independentes asociadas (FORTA e ARD).

6. Modelo de diversidade rexional nacional (Bélxica) mediante tres organizacións independentes (RTBF, VRT e BRF) para as comunidades francesa, flamenca e alemá, respectivamente.

7. Modelo estatal rexionalizado (Francia e Italia) con ventás e desconexións, tamén compartido por RTVE de España.

8. Modelo estatal de cooperación institucional e local (Reino Unido, Holanda e Irlanda). No caso do Reino Unido a través de 15 ventás rexionais da BBC para Inglaterra, Gales, Escocia e Irlanda de Norte, compartido coas canles locais das redes de ITV, STV de Escocia e UTV do Ulster.

9. Segundo os sistemas de gobernanza: a) órganos de control interno e externo independente e converxente (Reino Unido, Irlanda, Italia, Portugal, Bélxica, Austria, Finlandia e España); b) de control interno e externo audiovisual independente (Francia, Alemaña, Cataluña e Andalucía).

10. Segundo a súa penetración e audiencias respecto ás televisións privadas: a) de liderado e impacto maioritario (BBC e países nórdicos); b) de perda de influencia e menores audiencias (países mediterráneos).

A pesar desa tipoloxía de singularidades, os principais problemas da radiotelevisión pública son comúns e pasan pola súa perspectiva de futuro diante do novo escenario dixital no que o sistema dual tradicional europeo (público-privado) é moito máis aberto e complexo que hai dez anos. Eses principais problemas pódense concretar 
en cinco aspectos de regulación, financiamento, gobernanza, rendición de contas e reconversión e innovación. Por iso, o documento DCMS Green Paper on Charter Renewal da BBC, ao que voltaremos máis adiante, ten tanta importancia como rumbo estratéxico de futuro. Con eses cinco problemas estruturais en mente e o documento da Secretaría de Cultura (DCMS) do Reino Unido á man poñemos por diante neste documento dez ideas sobre o futuro da radiotelevisión pública europea.

1.- As políticas de regulación e comunicación, tanto da Unión Europea como dos seus Estados, teñen que ser menos retóricas e máis realistas ou concretas sobre o futuro do servizo público audiovisual se queren autorrecoñecer e proxectar a súa diversidade de sociedades no contexto da sociedade global.

Non só o futuro, senón tamén o presente, da radiotelevisión é dixital e audiovisual. A radiotelevisión do século XXI é un servizo audiovisual que cada vez converxe máis con Internet. Chama moito a atención que o documento BBC Paper on Charter Renewal para a súa nova Carta Real 2017-2027 non mencione a televisión dixital terrestre, que en 2022 pasará da banda 470-862 MHz á de 470-694 MHz. Pero desta última tamén pode ser excluída pola presión e requirimento de maior espazo radioeléctrico dos operadores de telefonía móbil. Esta posibilidade cambiaría radicalmente os modelos de difusión e negocio do audiovisual, que pasarían integramente a Internet. Se isto vai adiante -o tema só foi temporalmente descartado ata 2030 na Conferencia Mundial de Radiocomunicacións-, á radiotelevisión tradicional, masiva e aberta, que hoxe coñecemos -principalmente á de propiedade pública- quédanlle apenas 15 anos de vida.

Por iso, vale a pena a reflexión e a chamada de atención sobre o futuro dos servizos audiovisuais públicos en Europa, tras dúas décadas de políticas brandas e desregulatorias. O modelo tradicional de eclecticismo dual público-privado non vale para a próxima década porque Europa, os seus estados e as comunidades nacionais con competencias transferidas nesa materia terán que decantarse por atopar un novo estatuto de reestruturación e promoción do audiovisual público ou dar vía libre ao seu desmantelamento final. Se a opción é a favor da salvagarda, a tarefa urxente é impulsar e asentar a estratexia dixital.

O documento oficial da consulta pública do Goberno británico sobre a reforma da Carta Real da BBC aborda as mesmas cinco cuestións formuladas de carácter xeral ao inicio desta epígrafe: misión e propósito da BBC, servizos que debe prestar, modo de financiamento, gobernanza e transparencia. A propia presentación do propio informe británico acendeu a polémica, por estar a cargo do novo secretario de Cultura, John Whittingadle, un dos «falcóns» do partido conservador e crítico coa BBC pola súa chamada «cultura da progresía». A propia prensa británica xa se posicionou claramente en dous bandos, un deles crítico -The Times, The Daily Telegraph, Daily Mail- e claramente a favor de recortarlle o voo á corporación pública británica, e outro (The Guardian e Daily Mirror) máis condescendente. A nivel de partidos, os conservadores, que gobernan, están por unha reforma con redimensionamento da corporación; e os laboristas, co novo líder Jeremy Corbyn á fronte, a favor da potenciación para compensar a falla de apoios que teñen da prensa privada. A este respecto, tras o referendo do Brexit e o debate sobre o liderado no Partido Laborista, a BBC foi acusada de tratamento parcial en contra de Corbyn por varios académicos e investigadores, entre os que destacan Annabelle Sreberny, Graham Murdock, David Hesmondhalgh, Greg Philo, David Miller, Bev Skeggs e Martin Moore. Ese desequilibrio foi atribuído á autocensura interna por temor ao último tramo de negociación da Carta Real co Goberno conservador.

A proposta de reforma do Goberno británico para a BBC dos próximos dez anos somete a reflexión o ata agora inamovible principio da universalidade do servizo público por algo máis concreto e específico, así como a súa escala e alcance. Malia recoñecer a importancia nacional e global da BBC (chega ao 75 \% dos británicos cada semana e a 300 millóns de persoas en todo o mundo), consideran os tories que o servizo público de ningún modo pode socavar os intereses dos operadores audiovisuais privados. Reclámanlle á corporación máis transparencia, rendición de contas e políticas de control dos escándalos coma os ocorridos en 2012 (casos de pedofilia do ex-presentador Jimmy Savile e das acusacións non verificadas contra o Lord Alistair McAlpine). 
Para a súa gobernanza, o Executivo conservador propuxo a supresión do BBC Trust (creado en 2010 e que representa os intereses dos abonados) e, tamén, tres alternativas: un consello de administración unitario de xestión e control, un órgano interno de control independente ou unha entidade externa de supervisión (o actual regulador converxente, OFCOM).

E para o financiamento da BBC, o Goberno suxeriu tres alternativas: un canon reformado para fogares e todos os dispositivos de radiotelevisión (ata agora só se pagaba polo televisor e non pola recepción a través de Internet, por exemplo na canle iPlayer), un sistema híbrido (taxa e publicidade ou subvención) e, a medio prazo, un sistema de subscrición, coma o da televisión privada. Como se pode apreciar, a reforma da Carta Real abre as portas de par en par da BBC ao futuro de Internet.

2. - Establecemento dunha nova estratexia para o audiovisual conectado e multiplataforma. Diante dun contexto globalizado de sistemas multiplataforma e de intermediarios dixitais globais de agregación de contidos, seguen sendo necesarios os operadores estatais e de proximidade. A UER e os grandes operadores públicos (BBC, ZDF, ARD, FT) así o ven e por iso buscan alianzas para non perder oportunidades de competencia a nivel dixital e global. A televisión do presente e do futuro inmediato é unha tableta polivalente que conecta múltiples canles e metaservizos dixitais de comunicación.

3. - O servizo público debe recuperar terreo a través dos medios sociais dixitais para fortalecer a democracia porque a esfera pública é unha interface que conecta cultura, economía e política na sociedade actual (Fuchs 2014). Esta idea require máis vontade e firmeza das políticas europeas (non só da revisión da Directiva 2010/13UE de servizos audiovisuais e da Axenda Dixital Europea) a través dunha nova estratexia global para a comunicación audiovisual por Internet.

No caso de España e das súas comunidades autónomas, é tamén necesaria de novo a reforma da Lei xeral estatal do audiovisual 7/2010 e a Lei 9/2011 dos medios audiovisuais públicos de Galicia, parcialmente inaplicada cinco anos despois da súa aprobación. 0 marco regulatorio do audiovisual español -intervido pola politización partidista de cada un dos gobernos do momento- segue estando obsoleto e indo moito por detrás dos cambios que se producen no sector.

4.- As malas prácticas de gobernanza deben ser corrixidas mediante modelos expertos, transparentes e avaliados, de regulación, autorregulación e corregulación. Os órganos de regulación e gobernanza dos medios audiovisuais públicos seguen sendo patrimonializados por partidos políticos, sindicatos e asesores/as de comunicación a cambio de prebendas e formas indirectas non transparentes de autofinanciamento dos e das representantes desas institucións.

Fronte a ese modelo de meritocracia política, debería desenvolverse unha alternativa de meritocracia técnica experta independente, transparente e sometida a rendición pública de contas. A regulación da gobernanza institucional debería combinarse con sistemas máis esixentes de autorregulación (rendición de contas, probas de valor público, informes de Responsabilidade Social Corporativa) e de corregulación diante de consellos audiovisuais sectoriais ou converxentes.

5.- As radiotelevisións públicas deben evolucionar da audimetría comercial a outros novos modelos de indicadores de servizo público converxente. Se o seu modelo de negocio non é ou é cada vez menos a comercialización publicitaria mediante a economía da atención, a medición cuantitativa de audiencias xa non se corresponde coa súa propia identidade.

Non se trata só de evolucionar cara a unha nova medición de audiencias sociais senón tamén de buscar outros novos sistemas cualitativos e experimentais de relación cos usuarios dos servizos audiovisuais, na liña da alfabetización mediática e das alternativas de empoderamento a través das web converxentes (método Damian, por exemplo) para aproveitar a conversación social para a transparencia, autocontrol e recuperación da credibilidade e impacto dos servizos audiovisuais públicos. A deflación dos indicadores tradicionais de audiencia das radiotelevisións públicas aconsella, cando menos, unha seria reflexión sobre a busca de alternativas a esa perda de penetración. 
Cadro 7. Evolución das audiencias de TV en España, 1992-2015

19921993199419951996199719981999200020012002200320042005200620072008200920102011201220132014 *2015

\begin{tabular}{|c|c|c|c|c|c|c|c|c|c|c|c|c|c|c|c|c|c|c|c|c|c|c|c|}
\hline .al & 325 & 298 & 27,6 & 627,6 & 26,9 & 25,2 & 25,6 & 24,9 & 24,5 & 24,8 & 24,7 & 23,4 & 21,4 & 19,6 & $18,3 \quad 17,2$ & 16,9 & 16,4 & 16 & 14,5 & 12,21 & 10,2 & 10 & 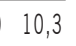 \\
\hline La2 & 8 & 9,5 & 9,8 & 99,2 & 9,1 & 8,9 & 8,8 & 8,1 & 7,9 & 7,8 & 7,7 & 7,2 & 6,8 & 5,8 & $\begin{array}{ll}4,8 \quad 4,6 \\
\end{array}$ & 4,5 & 3,8 & 3,1 & 2,6 & 2,5 & 2,4 & 2,8 & 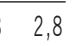 \\
\hline AN & 0 & 0 & 0 & 0 & 0 & 0 & 0 & 0 & 0 & 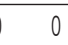 & 0 & 0 & 0 & 0 & $0,1 \quad 0,2$ & 0,6 & 1,4 & 3,2 & 3,2 & 2,5 & 2,4 & 2,3 & $?$ \\
\hline & 0 & 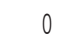 & 0 & 0 & 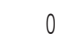 & 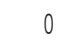 & 0 & 0 & 0 & 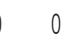 & 0 & 0 & 0 & 0 & $0 \quad 0,1$ & 0,2 & 0,4 & 0,7 & 0,9 & 0,9 & 0,8 & 0,8 & 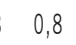 \\
\hline LED & 0 & 0 & 0 & 0 & 0 & 0 & 0 & 0 & 0 & 0 & 0 & 0 & 0 & 0,1 & $0,1 \quad 0,3$ & 0,4 & 0,6 & 1,1 & 1 & 0,8 & 0,9 & 0,9 & 0,7 \\
\hline UPC & 3 & 39,3 & 37,4 & 36,7 & 36 & 34,1 & 34,4 & 33 & 32,4 & 32,6 & 32,4 & 30,7 & 28,3 & 25,4 & $23,3 \quad 22,4$ & 22,6 & 22,7 & 24,1 & 22,3 & 18,91 & 16,7 & 16,7 & 16,7 \\
\hline 2 & 20,7 & 21,4 & 19 & 918,5 & 20,2 & 21,7 & 20,4 & 21 & 22,3 & 21,1 & 20,3 & 21,4 & 22,1 & 22,3 & $21,2 \quad 20,3$ & 18,1 & 15,1 & 14,6 & 14,2 & 13,91 & 13,5 & 14,5 & 14,8 \\
\hline ET & 0 & 0 & 0 & 0 & 0 & 0 & 0 & 0 & 0 & 0 & 0 & 0 & 0 & 0 & 0 & 0,1 & 0,6 & 1,4 & 1,5 & 1,4 & 1,2 & 0,3 & \\
\hline F.T5 & 0 & 0 & 0 & 0 & 0 & 0 & 0 & 0 & 0 & 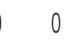 & 0 & 0 & 0 & 0 & 0 & 0,2 & 0,5 & 1,5 & 2,6 & 2,9 & 2,9 & 3,5 & 3, \\
\hline $30 I N G$ & 0 & & 0 & 0 & 0 & 0 & 0 & 0 & 0 & 0 & 0 & 0 & 0 & 0 & 0 & 0 & 0 & 0,2 & 1,1 & 1,7 & 1,7 & 1,7 & 1 \\
\hline TRO & 0 & 0 & 0 & 0 & 0 & 0 & 0 & 0 & 0 & 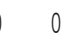 & 0 & 0 & 0 & 0,8 & $6,4 \quad 7,7$ & 8,6 & 8,2 & 7 & 6,1 & 6 & 6 & 6,7 & 7 \\
\hline VINITY & 0 & 0 & 0 & 0 & 0 & 0 & 0 & 0 & 0 & 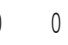 & 0 & 0 & 0 & 0 & 0 & 0 & 0 & 0 & 0,7 & 1,4 & 1,7 & 2,1 & 2 \\
\hline ERG & 0 & 0 & 0 & 0 & 0 & 0 & 0 & 0 & 0 & 0 & 0 & 0 & 0 & 0 & 0 & 0 & 0 & 0 & 0 & 0,9 & 1,2 & 1,5 & ; \\
\hline DIAS & 7 & 21,4 & 19 & 18,5 & 20,2 & 21,7 & 20,4 & 21 & 22,3 & 21,1 & 20,3 & 21,4 & 22,1 & 23,1 & $27,6 \quad 28$ & 27 & 24,4 & 24,7 & 26,2 & 28,12 & 28,3 & 30,4 & 31,4 \\
\hline 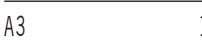 & 14,7 & 21,1 & 25,7 & 26 & 25 & 22,9 & 22,8 & 22,8 & 21,6 & 20,5 & 20,3 & 19,5 & 20,8 & 21,3 & $19,4 \quad 17,4$ & 16 & 14,7 & 11,7 & 11,5 & 12,51 & 13,4 & 13,6 & 13 \\
\hline VA & 0 & 0 & 0 & 0 & 0 & 0 & 0 & 0 & 0 & 0 & 0 & 0 & 0 & 0 & $0,1 \quad 0,1$ & 0,4 & 0,7 & 1,5 & 1,5 & 1,6 & 2,1 & 2,5 & 2 \\
\hline IEOX & 0 & 0 & 0 & 0 & 0 & 0 & 0 & 0 & 0 & 0 & 0 & 0 & 0 & 0 & $0,1 \quad 0,2$ & 0,6 & 1,2 & 2,2 & 2,7 & 2,6 & 2,3 & 2,6 & 2, \\
\hline $\mathrm{RO}^{*}$ & 0 & 0 & 0 & 0 & 0 & 0 & 0 & 0 & 0 & 0 & 0 & 0 & 0 & 0 & 0 & 0 & 0 & 0,4 & 1,4 & 1,6 & 1,7 & 0,6 & \\
\hline SEXT & 0 & 0 & 0 & 0 & 0 & 0 & 0 & 0 & 0 & 0 & 0 & 0 & 0 & 0 & 0 & 0 & 0 & 0,1 & 0,6 & 0,2 & 0 & 0 & 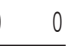 \\
\hline SEX & 0 & 0 & 0 & 0 & 0 & 0 & 0 & 0 & 0 & 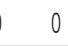 & 0 & 0 & 0 & 0 & 0 & 0 & 0 & 0,1 & 1,4 & 1,6 & 1,6 & 0,6 & \\
\hline SEXT & 0 & 0 & 0 & 0 & 0 & 0 & 0 & 0 & 0 & 0 & 0 & 0 & 0 & 0 & 1,8 & 5,5 & 6,8 & 6,6 & 5,7 & 4,9 & 6 & 7,2 & 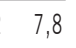 \\
\hline RESMEDIA & 4,7 & 21,1 & & 726 & 26 & 22,9 & 22,8 & 22,8 & 21,6 & 20,5 & 20,3 & 19,5 & 20,8 & 21,3 & $21,3 \quad 21,8$ & 22,5 & 23,4 & 22,6 & 24,7 & 24,92 & 27,1 & 27,1 & 26,7 \\
\hline NEY & 0 & 0 & 0 & 0 & 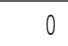 & 0 & 0 & 0 & 0 & 0,1 & 0,1 & 0,1 & 0,1 & 0,1 & $0,2 \quad 0,1$ & 0,4 & 1,4 & 2,1 & 1,7 & 1,6 & 1,5 & 1,5 & 1, \\
\hline NTEREC & 0 & 0 & 0 & 0 & 0 & 0 & 0 & 0 & 0 & 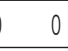 & 0 & 0 & 0 & 0 & 0 & 0,1 & 0,5 & 1,1 & 1,4 & 1,2 & 0,9 & 0,1 & \\
\hline$V * *$ & 0 & 0 & 0 & 0 & 0 & 0 & 0 & 0 & 0 & 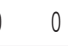 & 0 & 0 & 0 & 0 & 0 & 0 & 0 & 0,1 & 0,5 & 0,7 & 0,6 & 0,1 & \\
\hline PARAMO & $\begin{array}{cl}\text { EL } & 0 \\
\end{array}$ & 0 & 0 & 0 & 0 & 0 & 0 & 0 & 0 & 0 & 0 & 0 & 0 & 0 & 0 & 0 & 0 & 0 & 0 & 0,8 & 1,4 & 1,9 & 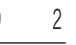 \\
\hline RUPO & 0 & 0 & 0 & 0 & 0 & 0 & 0 & 0 & 0 & 0,1 & 0,1 & 0,1 & 0,1 & 0,1 & $0,2 \quad 0,1$ & 0,5 & 1,9 & 3,3 & 3,6 & 4,4 & 4,4 & 3,5 & 3,4 \\
\hline V & 0 & 0 & 0 & 0 & 0 & 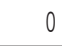 & 0 & 0 & 0 & 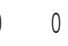 & 0 & 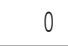 & 0 & 0 & 0 & 0 & 0 & 0 & 0,4 & 1 & 1,3 & 1,6 & 1, \\
\hline MARCA TV & 0 & 0 & 0 & 0 & 0 & 0 & 0 & 0 & 0 & 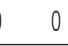 & 0 & 0 & 0 & 0 & 0 & 0 & 0 & 0,2 & 0,8 & 1 & 0,6 & 0 & ) \\
\hline ISCOV & 0 & 0 & 0 & 0 & 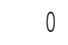 & 0 & 0 & 0 & 0 & 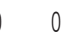 & 0 & 0 & 0 & 0 & 0 & 0 & 0 & 0 & 0 & 1,2 & 1,6 & 2,1 & 2, \\
\hline GRUPO UNID. ED. & 0 & 0 & 0 & 0 & 0 & 0 & 0 & 0 & 0 & 0 & 0 & 0 & 0 & 0 & 0 & 0 & 0 & 0,2 & 1,2 & 3,2 & 3,5 & 3,6 & 3 \\
\hline$\varepsilon$ & 8 & & 1 & 81,2 & 81,2 & 78,7 & 77,6 & 76,8 & 76,3 & 74,3 & 73,1 & 71,7 & 71,3 & 69,9 & $72,4 \quad 72,3$ & 72,6 & 72,4 & 74,9 & 78 & 79,5 & 80 & 81,3 & 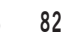 \\
\hline
\end{tabular}

O contraste da evolución dos resultados de audiencia da televisión pública e privada en España é rechamante no transcurso dos últimos 20 anos. As televisión públicas acaparaban en 1992 o $65 \%$ da audiencia fronte ao $30 \%$ das privadas, pero 23 anos despois as tornas vólvense ao revés. As autonómicas resisten mellor arredor do $10 \%$ as canles das comunidades históricas, entre elas a de Galicia. 
Cadro 8. Audiencias das TV autonómicas, 1992-2015

19921993199419951996199719981999200020012002200320042005200620072008200920102011201220132014 *2015

\begin{tabular}{lllllllllllllllllllllllllll}
\hline TVG & 17 & 15,5 & 14,6 & 15,4 & 16,5 & 18,5 & 18,1 & 18,6 & 19 & 18,3 & 16,7 & 18 & 17,4 & 17,2 & 14,4 & 14,1 & 15,5 & 14,3 & 12,3 & 12,3 & 11,5 & 10,9 & 10 & 9,8
\end{tabular}

\begin{tabular}{llllllllllllllllllllllllll}
\hline TVG2 & 0 & 0 & 0 & 0 & 0 & 0 & 0 & 0 & 0 & 0 & 0 & 0 & 0 & 0 & 0 & 0 & 0 & 0,1 & 0,8 & 0,9 & 0,9 & 0,9 & 0,8 & 0,7
\end{tabular}

\begin{tabular}{lllllllllllllllllllllllll}
\hline GRUPO CRTVG & 17 & 15,5 & 14,6 & 15,4 & 16,5 & 18,5 & 18,1 & 18,6 & 19 & 18,3 & 16,7 & 18 & 17,4 & 17,2 & 14,4 & 14,1 & 15,5 & 14,4 & 13,2 & 13,2 & 12,4 & 11,8 & 10,9 & 10,4
\end{tabular} \begin{tabular}{lllllllllllllllllllllllllll}
\hline CSUR HD & 0 & 0 & 0 & 0 & 0 & 0 & 0 & 0 & 0 & 0 & 0 & 0 & 0 & 0 & 0 & 0 & 0 & 0 & 0 & 0 & 0 & 0 & 0 & 0,3
\end{tabular} \begin{tabular}{llllllllllllllllllllllllll}
\hline C. SUR & 20,1 & 18,9 & 16,6 & 16,4 & 16,3 & 19,5 & 19,5 & 18,8 & 17,8 & 17,3 & 17,2 & 17,9 & 19,2 & 20,2 & 17,5 & 16,9 & 16,8 & 15,6 & 12,7 & 10,7 & 10,1 & 9,9 & 9,5 & 9,1
\end{tabular} \begin{tabular}{lllllllllllllllllllllllllll}
\hline $\operatorname{CS2}^{* *}$ & 0 & 0 & 0 & 0 & 0 & 0 & 0,5 & 2,1 & 3,5 & 4,2 & 4,6 & 5,2 & 5,5 & 5,5 & 4,2 & 3,9 & 4,1 & 3,2 & 1,9 & 1,5 & 1 & 0 & 0 & 0
\end{tabular} \begin{tabular}{lllllllllllllllllllllllll}
\hline GRUPO C. SUR & 20,1 & 18,9 & 16,6 & 16,4 & 16,3 & 19,5 & 20 & 20,9 & 21,3 & 21,5 & 21,8 & 23,1 & 24,7 & 25,7 & 21,7 & 20,8 & 20,9 & 18,8 & 14,6 & 12,2 & 11,1 & 9,9 & 9,5 & 9,4
\end{tabular} \begin{tabular}{llllllllllllllllllllllllllll}
\hline TV3 & 21,5 & 19,2 & 22,5 & 21,4 & 19,1 & 22 & 23,6 & 22,1 & 21,2 & 21,8 & 21,4 & 21,1 & 19,9 & 19,6 & 18,2 & 16,6 & 14,6 & 14,5 & 14,8 & 14,1 & 14,3 & 13,5 & 12,6 & 12,6
\end{tabular} \begin{tabular}{llllllllllllllllllllllllll}
\hline $33^{* *}$ & 6,1 & 5,6 & 5,2 & 4,3 & 6,9 & 7,1 & 5,7 & 5,2 & 5,1 & 6,1 & 7 & 6,8 & 6,2 & 5,3 & 4,3 & 3,4 & 2,9 & 1,9 & 1,6 & 1,6 & 1,1 & 0 & 0 & 0
\end{tabular} \begin{tabular}{lllllllllllllllllllllllll}
\hline SUPER 3/33 & 0 & 0 & 0 & 0 & 0 & 0 & 0 & 0 & 0 & 0 & 0 & 0 & 0 & 0 & 0,3 & 0,5 & 0,5 & 0,7 & 1,1 & 1,1 & 1,3 & 1,2 & 1,3 & 1,4
\end{tabular} \begin{tabular}{llllllllllllllllllllllllll}
\hline SUPER 3** & 0 & 0 & 0 & 0 & 0 & 0 & 0 & 0 & 0 & 0 & 0 & 0 & 0 & 0 & 0 & 0,1 & 0,4 & 0,5 & 1,3 & 1,6 & 1,1 & 0 & 0 & 0 \\
\hline
\end{tabular} \begin{tabular}{lllllllllllllllllllllllll}
\hline ESPORT3 & 0 & 0 & 0 & 0 & 0 & 0 & 0 & 0 & 0 & 0 & 0 & 0 & 0 & 0 & 0 & 0 & 0 & 0 & 0 & 0,9 & 1,1 & 1,4 & 1,2 & 1,2 \\
\hline
\end{tabular} \begin{tabular}{lllllllllllllllllllllllllll}
\hline GRUPO TV3 & 27,6 & 24,8 & 27,7 & 25,7 & 26 & 29,1 & 29,3 & 27,3 & 26,3 & 27,9 & 28,4 & 27,9 & 26,1 & 24,9 & 22,8 & 20,6 & 18,4 & 17,6 & 18,8 & 19,3 & 18,9 & 16,1 & 15,1 & 15,2
\end{tabular} \begin{tabular}{llllllllllllllllllllllllll}
\hline ETB1 & 4,3 & 5,5 & 5,1 & 5,9 & 6,7 & 7,5 & 6,7 & 5,4 & 4,6 & 5,3 & 5,6 & 6,2 & 5,3 & 5 & 4,4 & 3,7 & 3,4 & 3,2 & 2,2 & 2 & 2,1 & 2,1 & 2 & 1,9 \\
\hline
\end{tabular} \begin{tabular}{llllllllllllllllllllllllll}
\hline ETB2 & 9,4 & 10,7 & 12,4 & 14,8 & 16,1 & 17,2 & 16,5 & 15,6 & 16,3 & 17,8 & 18,5 & 18 & 17,1 & 18,4 & 15,8 & 14,8 & 15,1 & 13,4 & 9,4 & 8,2 & 9,9 & 9,6 & 9 & 8,9 \\
\hline
\end{tabular}

ETB3

GRUPO ETB

$\begin{array}{llllllllllllllllllllllll}0 & 0 & 0 & 0 & 0 & 0 & 0 & 0 & 0 & 0 & 0 & 0 & 0 & 0 & 0 & 0 & 0,1 & 0,3 & 0,5 & 0,7 & 0,9 & 0,9 & 0,9 & 0,6\end{array}$
\begin{tabular}{lllllllllllllllllllllllll}
\hline TELEMADRID & 18,4 & 18,8 & 17,8 & 20 & 19 & 20,3 & 20,6 & 20 & 19,7 & 17,8 & 17,2 & 17,1 & 14,9 & 14,4 & 11,6 & 10,5 & 10,5 & 9,7 & 8 & 6,4 & 5,3 & 3,8 & 4,2 & 4,1 \\
\hline
\end{tabular} \begin{tabular}{lllllllllllllllllllllllll}
\hline LAOTRA & 0 & 0 & 0 & 0 & 0 & 0 & 0 & 0 & 0 & 0 & 0 & 0 & 0 & 0 & 0,1 & 0,2 & 0,3 & 0,4 & 0,7 & 0,8 & 0,9 & 0,7 & 0,8 & 0,8 \\
\hline
\end{tabular}

\begin{tabular}{lllllllllllllllllllllllll}
\hline GRUPO TVM & 18,4 & 18,8 & 17,8 & 20 & 19 & 20,3 & 20,6 & 20 & 19,7 & 17,8 & 17,2 & 17,1 & 14,9 & 14,4 & 11,7 & 10,7 & 10,8 & 10,1 & 8,7 & 7,2 & 6,2 & 4,5 & 5 & 4,9
\end{tabular}
\begin{tabular}{lllllllllllllllllllllllll}
\hline $\mathrm{Cg**}$ & 23,5 & 19,9 & 17,7 & 18,5 & 17,3 & 20,6 & 18,2 & 18,7 & 20,2 & 18,7 & 18,4 & 18,2 & 17 & 16,3 & 14,3 & 12,7 & 12 & 11,8 & 8,4 & 6 & 5 & 3,7 & 0 & 0
\end{tabular} \begin{tabular}{llllllllllllllllllllllllll}
\hline NOUDOS** & 0 & 0 & 0 & 0 & 0 & 0,1 & 0,9 & 1,4 & 2 & 2 & 1,8 & 2 & 2,1 & 2,4 & 2,1 & 1,8 & 1,3 & 0,6 & 0,5 & 0,4 & 0,4 & 0,2 & 0 & 0
\end{tabular} \begin{tabular}{lllllllllllllllllllllllll}
\hline NOU24** & 0 & 0 & 0 & 0 & 0 & 0 & 0 & 0 & 0 & 0 & 0 & 0 & 0 & 0 & 0 & 0 & 0 & 0,5 & 0,3 & 0,3 & 0,3 & 0,4 & 0 & 0 \\
\hline
\end{tabular} \begin{tabular}{llllllllllllllllllllllllll}
\hline GRUPO TVV & 22,5 & 19,9 & 17,7 & 18,5 & 17,3 & 20,7 & 19,1 & 20,1 & 22,2 & 20,7 & 20,2 & 20,2 & 19,1 & 18,7 & 16,4 & 14,5 & 13,3 & 12,9 & 9,2 & 6,7 & 5,7 & 4,3 & 0 & 0
\end{tabular} \begin{tabular}{lllllllllllllllllllllllllll}
\hline CMT & 0 & 0 & 0 & 0 & 0 & 0 & 0 & 0 & 0 & 0 & 7,3 & 11,1 & 11,6 & 12,8 & 12 & 11,1 & 10,2 & 10,3 & 7,5 & 6,4 & 5,1 & 4,4 & 4,6 & 4,3
\end{tabular} \begin{tabular}{lllllllllllllllllllllllll}
\hline CMT2** $^{* *}$ & 0 & 0 & 0 & 0 & 0 & 0 & 0 & 0 & 0 & 0 & 0 & 0 & 0 & 0 & 0 & 0 & 0 & 0,2 & 0,7 & 0,6 & 0 & 0 & 0 & 0 \\
\hline
\end{tabular} \begin{tabular}{lllllllllllllllllllllllll}
\hline GRUPO CMT & 0 & 0 & 0 & 0 & 0 & 0 & 0 & 0 & 0 & 0 & 7,3 & 11,1 & 11,6 & 12,8 & 12 & 11,1 & 10,2 & 10,5 & 8,2 & 7 & 5,1 & 4,4 & 4,6 & 4,3 \\
\hline
\end{tabular}

\begin{tabular}{lllllllllllllllllllllllll}
\hline TVCAN & 0 & 0 & 0 & 0 & 0 & 0 & 0 & 0,8 & 5,4 & 7,1 & 11,1 & 12,7 & 10,3 & 9,9 & 9,2 & 9,3 & 10,2 & 11,6 & 10 & 7,9 & 7,6 & 7,2 & 7,3 & 7
\end{tabular}

\begin{tabular}{llllllllllllllllllllllllll}
\hline TVCAN2** $^{2}$ & 0 & 0 & 0 & 0 & 0 & 0 & 0 & 0 & 0 & 0 & 0 & 0 & 0 & 0 & 0 & 0 & 0,2 & 0,6 & 1 & 1 & 0,5 & 0 & 0 & 0
\end{tabular}

\begin{tabular}{lllllllllllllllllllllllll}
\hline GRUPO TVCAN & 0 & 0 & 0 & 0 & 0 & 0 & 0 & 0,8 & 5,4 & 7,1 & 11,1 & 12,7 & 10,3 & 9,9 & 9,2 & 9,3 & 10,4 & 12,2 & 11 & 8,9 & 8,1 & 7,2 & 7,3 & 7
\end{tabular}
\begin{tabular}{lllllllllllllllllllllllllll}
\hline ARAGON TV & 0 & 0 & 0 & 0 & 0 & 0 & 0 & 0 & 0 & 0 & 0 & 0 & 0 & 0 & 4,7 & 6,7 & 8,8 & 9,6 & 9,4 & 10,7 & 11,3 & 11,5 & 11,3 & 11,1
\end{tabular}

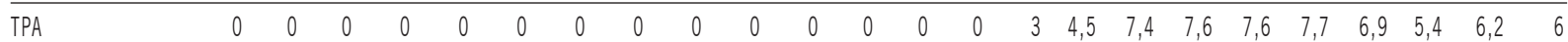

\begin{tabular}{lllllllllllllllllllllllll}
\hline TPA2 & 0 & 0 & 0 & 0 & 0 & 0 & 0 & 0 & 0 & 0 & 0 & 0 & 0 & 0 & 0 & 0 & 0,1 & 0,3 & 0,8 & 0,8 & 0,8 & 0,7 & 0,7 & 0,7
\end{tabular}

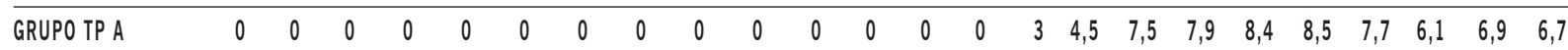

\begin{tabular}{lllllllllllllllllllllllll}
\hline IB3 & 0 & 0 & 0 & 0 & 0 & 0 & 0 & 0 & 0 & 0 & 0 & 0 & 0 & 0 & 6,7 & 6,5 & 4,7 & 5,1 & 5,5 & 5,2 & 6,3 & 5,9 & 5,8 & 6,1 \\
\hline
\end{tabular}

\begin{tabular}{lllllllllllllllllllllllll}
\hline $7 \mathrm{RM} * *$ & 0 & 0 & 0 & 0 & 0 & 0 & 0 & 0 & 0 & 0 & 0 & 0 & 0 & 0 & 1,5 & 2,8 & 4,1 & 5,2 & 4,6 & 4 & 2,5 & 0,5 & 0 & 0
\end{tabular}

\begin{tabular}{llllllllllllllllllllllllllll}
\hline AUTONÓMICAS & 16,5 & 15,6 & 15,1 & 15,5 & 15,3 & 16,9 & 16,6 & 16,4 & 17 & 17,2 & 17,9 & 18,4 & 17,7 & 17,6 & 15,4 & 14,7 & 14,5 & 13,6 & 11,3 & 10,4 & 9,8 & 8,7 & 8 & 7,7 \\
\hline
\end{tabular}

* 2015: Datos ata o 28/02/2015 inclusive

** Canles desaparecidas no 2015 
6. - A sustentabilidade e independencia do financiamento do servizo público audiovisual requiren novas fontes de ingresos máis aló da crise fiscal e publicitaria. O documento da BBC, que ata agora dispuxo do sistema máis estable e independente de financiamento, abriu o debate a novas fontes e alternativas. 0 modelo de negocio do servizo público audiovisual, que é social e non económico, ten que contemplar as posibilidades que ofrece Internet e, entre elas, o pago por visión e a subscrición. Polo momento, esas posibilidades están acoutadas pola comunicación europea de 2009, derivada do Protocolo de Amsterdam de 1997. Outra alternativa sería poñer enriba da mesa a comercialización de contidos premium e a corresponsabilidade de financiamento cívico -a través de crowfunding ou membresía de subscrición- para reforzar o servizo público e contrarrestar a manipulación político partidista da súa independencia. A crise fiscal dos estados dos últimos anos viuse reflectida na contención dos orzamentos das televisión públicas.

Cadro 9. Orzamentos das RTV públicas europeas

\begin{tabular}{|c|c|c|c|c|c|c|c|}
\hline Países & RTV & 2008 & 2009 & 2010 & 2011 & 2012 & 2013 \\
\hline Alemaña & ARD/ZDF & 8469,2 & 8745,9 & 8740,8 & 8867,2 & 8523,4 & $4180 \mathrm{ZDF}$ \\
\hline Austria & $\mathrm{ORF}$ & 1044,8 & 971,1 & 971,2 & 991,5 & 1001,9 & - \\
\hline Bélxica & VRT/RTBF/BRF & 783,8 & 799 & 787,8 & 776,5 & 796,6 & 323 RTBF \\
\hline Chipre & CyBC & 43,3 & 35,8 & 45 & 36,8 & 37,7 & - \\
\hline Croacia & HRT & - & 192,2 & 193,3 & 187,6 & 189,9 & - \\
\hline Dinamarca & $\mathrm{DR}$ & 786,4 & 763 & 805,8 & 828,6 & 872,6 & - \\
\hline Eslovaquia & RTVS & 103,6 & 103 & 101,9 & 114,1 & 97,4 & 121,8 \\
\hline Eslovenia & RTVSLO & - & 128,8 & 133,5 & 130,7 & 131,7 & \\
\hline España & RTVE/FORTA & 2675 & 2871 & 2794 & 2572 & 2165 & 1955,37 \\
\hline Estonia & ERR & 32,1 & 29,7 & 28,4 & 28,3 & 28,5 & 27,6 \\
\hline Finlandia & YLE & 397,5 & 411,2 & 420,1 & 432,5 & 456,1 & 469,1 \\
\hline Francia & FT & 4020,6 & 4246,7 & 4375,5 & 4443,1 & 4207 & - \\
\hline Grecia & ERT & 366 & 366,3 & 386 & 328,8 & - & - \\
\hline Hungría & MTV & - & 184,3 & 158 & 290 & 296,8 & - \\
\hline Irlanda & RTÉ & 440,8 & 374,9 & 371,7 & 350,9 & 337,2 & 327,6 \\
\hline Italia & RAI & 3315 & 3208 & 3040 & 2998 & 2761 & 2561,7 \\
\hline Lituania & LRT & 26,3 & 19,4 & 17,3 & 19 & 20,7 & 20,4 \\
\hline Malta & PBS & 6068 & 5832 & 8215 & 9071 & - & - \\
\hline Países Baixos & NPO & 815,1 & 829,2 & 857,2 & 855,9 & 864,5 & 799,2 \\
\hline Polonia & TVP & - & 489,5 & 497,5 & 475,7 & 393,1 & \\
\hline Portugal & RTP & 298,5 & 305,6 & 308,7 & 318,1 & 259 & 234,7 \\
\hline Reino Unido & BBC & - & 7850,3 & 7830,2 & 8091,3 & 7746,1 & 6439,5 \\
\hline R. Checa & CT & 330,6 & 333,3 & 337 & 321,9 & 316,5 & 246 \\
\hline Romanía & TVR & 205,6 & 211,7 & 211,4 & 215,8 & - & - \\
\hline Suecia & SVT & 711,7 & 694 & 751,5 & 756,8 & 786,9 & 792 \\
\hline
\end{tabular}

Fonte: elaboración propia a partir do Observatorio Audiovisual Europeo, 2014. Datos en millóns de euros e moedas locais dos países que non teñen a divisa europea.

7.- Reconverter as corporacións e canles de radiotelevisión en plataformas converxentes de comunicación. 0 modelo estrutural e organizativo de hai 25 anos é ineficiente e insostible hoxe en día. A estrutura e xestión das cor- 
poracións públicas ten que evolucionar cara a un ecosistema empresarial integrado por distintas unidades produtivas internas e externas, tanto profesionais como formadas polos seus propios usuarios. Deberán integrar radio, televisión, espazos web e redes sociais nunha mesma plataforma ou ecosistema converxente de xestión da información, entretemento e comunicación de múltiples colaboracións. O proxecto da nova Carta Real da BBC critica a burocracia e corporativismo ao mesmo tempo que abre a porta á privatización dalgunhas das súas unidades produtivas.

A clásica división de produción propia e allea, interna e externa, perde sentido nese novo ecosistema converxente porque todo pasa a ser propio, interno e externo ao mesmo tempo, pásase da metáfora de xestión da factoría á da torre de control do aeroporto. Evidentemente, esta concepción revoluciona e cambia a estrutura organizativa tradicional de forma radical. Quedan con pouco sentido os modelos departamentais, xerárquicos e matriciais, fronte ás necesidades de estímulos e necesidades horizontais de coordinación dos equipos operativos.

8.- Reconversión ou refundación do modelo. O dilema é máis teórico que práctico. A refundación, sen dúbida, podería ser teoricamente máis fácil que a reconversión pero, para empezar de novo, é necesario, primeiro, facer borrón e deseñar a conta nova. Xa imos vendo o que ocorre coas empresas que cerraron e volven empezar (casos de Grecia e Valencia). Xa imos vendo se a refundación só significa continuar cos vicios anteriores. Xa veremos como é a rexeneración. A rexeneración e a reconversión son posibilistas, porque dependen da vontade, pero non son máis fáciles nin menos complexas.

Para afrontar a reconversión, as corporacións públicas actuais teñen sobre elas catro pesadas lousas: unha regulación ríxida e anticuada, unhas bases de financiamento inestables cada vez máis axustadas, unhas pesadas infraestruturas técnicas obsoletas e uns cadros laborais sobrecargados, envellecidos e desaxeitados para afrontar o reto da converxencia dixital.

9.- A creatividade e a innovación como valores dinámicos de renovación do servizo público. Son elementos esenciais para a renovación do modelo e a innovación forma parte dos seis valores establecidos pola UER para o seu esquema de 24 indicadores de avaliación das probas de valor público. Eses seis principios da proba de valor público son a universalidade, excelencia, independencia, diversidade, innovación e rendición de contas. Estas probas son realizadas actualmente por seis televisións públicas europeas (BBC, ZDF, ARD, RTBF, DR, YLE y RAI) e outras doce elaboran tamén memorias de Responsabilidade Social Corporativa (ZDF, ORF, RTBF, RTVE, CRTVG, CMAC, EITB, YLE, FTV, RTE, RTP e BBC).

10.- Reforzo do discurso, presenza e representación institucional do servizo público audiovisual a nivel estatal e global. Refundada, reconvertida ou pendente de rexeneración, a radiotelevisión pública e o servizo audiovisual público necesitan reforzar tanto o seu discurso sobre a súa necesidade e defensa como a súa presenza e representación institucional. 0 discurso de rexeneración e defensa revitalizouse na Academia, mais languidece tanto na sociedade coma na propia gobernanza. Talvez por falta de capacidade de estratexia, escenarios e alternativas. Non obstante, os retos están reclamando novos movementos estratéxicos. A competitividade comercial e a representación diante de Bruxelas esixen maior eficacia da UER e esta debería abrirse definitivamente tamén aos pequenos operadores públicos rexionais e locais. No caso de España, as autonómicas de FORTA e a RTVE estatal deberían converxer nunha mesma plataforma de representación e distribución global.

\section{A INDUSTRIA DA COMUNICACIÓN EN GALICIA}

O panorama económico da industria da comunicación en Galicia nos últimos cinco anos, á vista das contas de resultados das súas principais empresas presentadas diante do Rexistro Mercantil, non é mellor nin moi diferente, na súa escala, das tendencias xerais de carácter global. No período de 2007 a 2012, a industria da comunicación en Galicia, se descartamos a facturación da empresa de telecomunicacións R, rexistrou un descenso da súa actividade económica dun 25 por cento, ao pasar de 337 millóns de euros a 225 millóns, respectivamente. A caída foi máis grande na radio e na prensa, con descensos do $51,6 \%$ e $36,25 \%$. 
Pero os problemas destas industrias, mirando cara ao escenario dos próximos dez anos, tampouco son menores no plano estratéxico que no económico. Entre eles pódense enumerar a falla de proxección estratéxica para a transición dixital, horizontes limitados e problemas de sucesión no liderado das principais empresas, carencias de fortaleza para a formación do capital necesario para acometer novos investimentos, forte apancamento e limitada capacidade de xeración de recursos para reducir os seus endebedamentos, pouca forza de creatividade e innovación, estruturas pesadas e burocráticas e perda de penetración (audiencias) da súa capacidade competitiva nos mercados de proximidade. A iso poderíase engadir a carencia de políticas institucionais de longo alcance, máis aló das solucións e rutinas conxunturais, para visualizar a situación e dependencia do sector no escenario do ano 2020.

Cadro 10. Resultados dos medios de Galicia, 2007-2014

\begin{tabular}{lrrrrrrrrrrrr}
\multicolumn{1}{c}{ Empresa } & \multicolumn{10}{c}{ Ingresos } \\
\hline Anos & 2013 & 2012 & 2011 & 2008 & 2007 & 2013 & 2014 & 2012 & 2011 & 2008 & 2007 & 2014 \\
\hline Grupo R & 239489 & 238157 & 230463 & 182922 & 134093 & 8081 & 234600000 & 12270 & 16717 & 14611 & 12053 & 92000000 \\
\hline CRTVG & 107900 & 117100 & 121500 & 131700 & 122900 & 1500 & 99470030 & 530 & 210 & 371 & 3700 & 312362 \\
\hline Voz Galicia & 52942 & 56451 & 60335 & 78308 & 83880 & 681 & 52591698 & 522 & -2487 & 2010 & 7368 & 862861 \\
\hline Faro de Vigo & 21101 & 22098 & 24749 & 28821 & 31276 & 204 & 20562119 & 1071 & 1972 & 3335 & 4979 & 1573798 \\
\hline Ed. Compostela & 14661 & 21518 & 22242 & 27196 & 28468 & -1017 & 14460490 & -1123 & -1375 & 367 & 343 & -1049600 \\
\hline La Región & 7847 & 8798 & 12064 & 13191 & 14894 & 174 & n. d. & -48 & 637 & 189 & 128 & n. d. \\
\hline El Progreso & - & - & 13094 & 16083 & 15819 & - & 11013164 & - & -201 & 731 & 854 & -316714 \\
\hline Lérez Edics. & 4069 & 4987 & 5095 & 5614 & 5547 & -272 & 3974913 & 52 & 218 & 107 & 69 & -245077 \\
\hline La Capital & 5448 & 6065 & 6612 & 7598 & 8400 & -646 & 5199397 & -842 & -621 & -250 & 324 & -706556 \\
\hline La Opinión & 3074 & 3289 & 3544 & 4710 & 5139 & -340 & 2735712 & -479 & -769 & -275 & 64 & -382334 \\
\hline Atlántico & - & 2209 & 3087 & 3031 & 3315 & - & $n . d$. & -416 & -403 & -515 & -392 & n. d. \\
\hline R Coruña & 1924 & 2315 & 2642 & 3464 & 3787 & -201 & 1946439 & 70 & 153 & 298 & 322 & -429431 \\
\hline R Lugo & 599 & 771 & 1003 & 1342 & 1415 & -259 & 705838 & -198 & -71 & 212 & 27 & -157716 \\
\hline R Orense & 709 & 919 & 949 & 1266 & 1327 & -48 & 790916 & 78 & 41 & 212 & 288 & 31366 \\
\hline R Pontevedra & 1572 & 1890 & 2076 & 2056 & 2190 & -174 & 1590977 & -83 & -98 & 181 & -395 & -5808 \\
\hline R Vigo & 1709 & 2417 & 2586 & 2938 & 3076 & 42 & 1739585 & 314 & 282 & 377 & 154 & 99089 \\
\hline Voz Radio & 1458 & 1922 & 2397 & 3399 & 3525 & -239 & 1671536 & -329 & -195 & 6 & 79 & -75774 \\
\hline R Principal & 278 & 302 & 359 & 415 & 419 & -39 & 288717 & -46 & -4 & 49 & 29 & -17706 \\
\hline C. Noroeste & 180 & 266 & 395 & 1704 & 1679 & -7 & n. d. & -7 & -287 & 11 & 8 & n. d. \\
\hline
\end{tabular}

Fonte: datos obtidos de SABI (Sistema de Análise de Balances Ibéricos), procedentes do Rexistro Mercantil. As cifras están en miles de euros. A sociedade de Atlántico Diario é Rías Baixas Comunicación SA, a de Ed. Compostela corresponde á cabeceira de El Correo Gallego, Lérez Edics. a Diario de Pontevedra e a de La Capital ao grupo de El Ideal Gallego.

A industria da comunicación en Galicia, incluíndo a actividade do Grupo R, que, ademais de telefonía e acceso a Internet, tamén presta servizos de difusión audiovisual, sumou 465 millóns de euros en 2013 fronte aos 471 millóns de 2007. Se descartamos os ingresos de explotación do grupo R, que en 2015 foi mercado por Eskaltel en 1190 millóns de euros, a facturación do resto da industria da comunicación baixou en 2014 a 218,74 millóns e os resultados pasaron a ser negativos en máis de medio millón de euros. 0 descenso do 4,3\% ascende ao $25 \%$ se descontamos a facturación de R e xuntamos a actividade audiovisual (da CRTVG e das produtoras audiovisuais), da prensa, da radio e da industria editorial, ao pasar de 337 millóns de euros de 2007 a 225,4 millóns de 2013. Ao sumar os seus resultados, en termos de beneficios ou perdas, pasan a ser negativos de 2011 a 2013. A perda 
de emprego neses sectores tamén é significativa porque acada o 13,4 \% ao baixar de 2716 postos de traballo de 2007 aos 2169 de 2013.

Hai que precisar que as cifras económicas que se recollen neste estudo e nas súas correspondentes táboas proceden das contas presentadas polas empresas diante do Rexistro Mercantil e procesadas polo Sistema de Análises de Balances Ibéricos (SABI). Naquelas epígrafes en que non se achegan cifras é por mor de que as empresas non presentaron eses datos diante do Rexistro Mercantil e que, polo tanto, non constan no sistema SABI.

Cadro 11. Emprego e endebedamento dos medios de Galicia

\begin{tabular}{lrrrrrrrrrrrr} 
Empresa & \multicolumn{10}{c}{ Emprego } \\
\hline Anos & 2013 & 2012 & 2011 & $\mathbf{2 0 0 8}$ & $\mathbf{2 0 0 7}$ & $\mathbf{2 0 1 4}$ & $\mathbf{2 0 1 3}$ & $\mathbf{2 0 1 2}$ & $\mathbf{2 0 1 1}$ & $\mathbf{2 0 0 8}$ & $\mathbf{2 0 0 7}$ & $\mathbf{2 0 1 4}$ \\
\hline CRTVG & 916 & 781 & 804 & 698 & 675 & 916 & 31,23 & 34,40 & 37,27 & 46,74 & 72,09 & 35 \\
\hline R Cable & 202 & 205 & 203 & 194 & 184 & - & 81,07 & 82,45 & 84,60 & 58,22 & 60,97 & - \\
\hline Voz Galicia & 328 & 358 & 411 & 545 & 540 & 316 & 40,17 & 44,60 & 45,16 & 43,42 & 53,84 & 32,76 \\
\hline Ed. Compostela & 154 & 170 & 199 & 209 & 199 & 178 & 87,52 & 91,84 & 87,80 & 82,47 & 81,81 & 96,53 \\
\hline La Región & 84 & 108 & 139 & 204 & 209 & 84 & 79,32 & 80,43 & 80,34 & 66,56 & 68,43 & 79,32 \\
\hline Faro Vigo & 146 & 160 & 160 & 177 & 184 & - & 24,17 & 26,60 & 23,15 & 26,67 & 31,56 & 28,33 \\
\hline El Progreso & 145 & 145 & 148 & 152 & 143 & 127 & - & - & 42,24 & 49,03 & 53,17 & 58,73 \\
\hline Lérez Edics. & 64 & 64 & 66 & 82 & 82 & 60 & 91,47 & 83,13 & 85,86 & 85,73 & 82,46 & 87,06 \\
\hline La Capital & 119 & 148 & 156 & 178 & 175 & 135 & 86,31 & 64,93 & 52,61 & 41,62 & 39,29 & 112,81 \\
\hline La Opinión & 44 & 51 & 59 & 74 & 75 & 42 & 51,27 & 71,76 & 93,13 & 70,70 & 61,78 & 52,88 \\
\hline Atlántico & 38 & 41 & 52 & 25 & 77 & n. d. & - & 72,37 & 56,30 & 131,34 & 105,7 & n. d. \\
\hline R Coruña & 26 & 30 & 31 & 38 & 38 & 23 & 45,13 & 40,47 & 36,73 & 33,64 & 31,94 & 74,23 \\
\hline R Lugo & 14 & 15 & 16 & 18 & 16 & 14 & 23,07 & 19,22 & 17,54 & 23,09 & 25,48 & 28,99 \\
\hline R Orense & 19 & 21 & 23 & 18 & - & 19 & 5,30 & 5,45 & 5,43 & 7,37 & 8,77 & 5,83 \\
\hline R Pontevedra & 14 & 17 & 17 & 21 & - & 14 & 37,04 & 15,76 & 19,80 & 27,91 & 37,07 & 30,77 \\
\hline R Vigo & 14 & 17 & 18 & 20 & 23 & 12 & 38,04 & 25,27 & 27,10 & 15,43 & 12,57 & 41,66 \\
\hline Voz Radio & 16 & 19 & 27 & 40 & 47 & 17 & 20,96 & 18,57 & 21,97 & 25,34 & 30,31 & 30,02 \\
\hline R Principal & 6 & 6 & 5 & 7 & 6 & 6 & 31,16 & 24,22 & 22,36 & 20,81 & 17,21 & 33,50 \\
\hline C. Noroeste & 3 & 14 & 16 & 42 & 43 & n. d. & 97,72 & 97,50 & 97,04 & 68,27 & 71,26 & n. d. \\
\hline & & & & & & & & & & &
\end{tabular}

Fonte: datos de $\mathrm{SABI}$ (que recolle do Rexistro Mercantil). As cifras están en miles de euros e as de débeda en porcentaxe.

A perda da actividade económica na prensa, radio e audiovisual, tomando como referencia os anos de 2007 e 2012 (por dispoñer de datos máis completos), está relacionada coa crise económica, co descenso no investimento publicitario e coa migración da economía do consumo analóxico ao dixital. Na radio a caída da actividade económica supera o $51 \%$, na prensa acada o $36 \%$, na produción audiovisual é do $35 \%$ e na industria editorial supera o $42 \%$. A perda de emprego na radio foi do $35 \%$, na prensa superou o $33 \%$ e no audiovisual chegou ao $26 \%$. As maiores cotas de apancamento financeiro corresponden ás organizacións de produción de editorial, case todas elas microempresas ou autónomos, seguidas das produtoras audiovisuais e das editoras de prensa. A radio segue a súa tradición de cotas máis baixas de endebedamento.

Os resultados da prensa impresa, con respecto ao conxunto de España, foron aínda peores que os de Galicia porque as súas vendas pasaron de 2426 millóns de euros en 2007 a 1176 millóns en 2013, o que significa unha caída do preto do 50 \% da súa facturación. E a súa conta de resultados agregada pasa de rexistrar 293 millóns de beneficios en 2007 a 64 millóns de perdas en 2012 e 29 millóns de recuperación positiva en 2013. 
A prensa en papel perdeu en Europa, entre 2009 e 2013, uns 39 millóns de exemplares de circulación diaria, un $17,45 \%$, segundo datos da Asociación Mundial de Diarios (WAN 2014). A prensa difunde diariamente no mundo uns 500 millóns de exemplares, dos cales 78,6 millóns corresponden a Europa (en 2009 eran 117,5 millóns). 0 afundimento da circulación da prensa impresa, tanto de pago como gratuíta, aínda foi maior en España porque pasou de 6,5 millóns de exemplares difundidos en 2009 a 2,6 millóns en 2013. Canto á difusión da prensa de pago, a baixada supera o 27 \%, ao pasar de 3537395 exemplares de 2008 aos 2568348 de 2013.

Cadro 12. Evolución da difusión da prensa

\begin{tabular}{lrrrrrrrr} 
Anos & $\mathbf{2 0 0 8}$ & $\mathbf{2 0 0 9}$ & $\mathbf{2 0 1 0}$ & $\mathbf{2 0 1 1}$ & $\mathbf{2 0 1 2}$ & $\mathbf{2 0 1 3}$ & $\mathbf{2 0 1 4}$ & $\mathbf{2 0 1 3 / 0 8}$ \\
\hline Total España & 3537395 & 3413657 & $3 \mathbf{3 9 4 7 2 7}$ & 3173279 & 2752460 & 2568348 & $1975006^{*}$ & $-27,39$ \\
\hline Total Galicia & 183586 & 179389 & 173886 & 166238 & 155797 & 144966 & 142792 & $-21,03$ \\
\hline Voz Galicia & 102858 & 100664 & 97016 & 91131 & 84843 & 80077 & $80077^{*}$ & $-22,14$ \\
\hline Faro de Vigo & 40336 & 39154 & 38004 & 36816 & 34804 & 31852 & 30234 & $-21,03$ \\
\hline El Progreso & 15846 & 15402 & 15258 & 14991 & 14219 & 13412 & $13412^{*}$ & $-15,36$ \\
\hline La Región & 11334 & 11324 & 11104 & 10906 & 10555 & 9200 & $9200^{*}$ & $-18,82$ \\
\hline D. Pontevedra & 7119 & 6917 & 6888 & 6867 & 6313 & 5742 & 5411 & $-19,34$ \\
\hline Opinión Coruña & 6093 & 5928 & 5616 & 5527 & 5063 & 4683 & 4458 & $-23,14$ \\
\hline
\end{tabular}

Fonte: datos dos xornais controlados por OJD. Compáranse os de 2008 e 2013 porque algúns de 2014 non están completos (*).

A difusión da prensa en Galicia, entre 2008 e 2013, baixou tamén por riba do 21 \%, aínda que tamén algo menos que no conxunto de España. Por cabeceiras, son as editadas na Coruña as que rexistran as porcentaxes máis altas de baixada. Tómanse como referencia, para os efectos comparativos, os datos de 2013 por non dispoñer das cifras completas de 2014 da Oficina de Justificación de la Difusión (OJD).

Botando man das enquisas do Estudio General de Medios (EGM), podemos calibrar o impacto do consumo e a audiencia de cada un dos principais medios de comunicación. O consumo de prensa diaria en España entre 2008 e 2014, segundo os datos do EGM, baixou do $42,1 \%$ ao 29,8 \%, respectivamente. Case unha mesma tendencia rexistran os suplementos e revistas. Polo contrario, subiu de forma importante o consumo de radio, sobre todo a de carácter temático. Tamén sobe o consumo de televisión e o uso de Internet.

Cadro 13. Consumo de medios, 2008-2014

\begin{tabular}{lrrrrrrr} 
Anos & $\mathbf{2 0 0 8}$ & $\mathbf{2 0 0 9}$ & $\mathbf{2 0 1 0}$ & $\mathbf{2 0 1 1}$ & $\mathbf{2 0 1 2}$ & $\mathbf{2 0 1 3}$ & $\mathbf{2 0 1 4}$ \\
\hline Universo & 38261 & 39462 & 39435 & 39485 & 39449 & 39331 & 39681 \\
\hline Diarios & 42,1 & 39,8 & 38,0 & 37,4 & 36,1 & 32,4 & 29,8 \\
\hline Suplementos & 21,7 & 21,9 & 19,2 & 18,2 & 16,2 & 14,6 & 12,7 \\
\hline Revistas & 53,3 & 51,3 & 50,4 & 48,9 & 45,4 & 43,4 & 41,0 \\
\hline Total radio & 53,1 & 55,3 & 56,9 & 58,5 & 61,9 & 61,5 & 61,0 \\
\hline Radio xeralista & 27,9 & 27,9 & 27,8 & 28,3 & 30,2 & 29,2 & 28,7 \\
\hline Radio temática & 28,5 & 31,1 & 33,0 & 34,6 & 37,3 & 37,4 & 37,4 \\
\hline Radio por Internet & 4,1 & 3,9 & 3,5 & 3,4 & 3,4 & 2,9 & 2,9 \\
\hline Televisión & 49,0 & 51,0 & 52,4 & 53,8 & 56,9 & 56,5 & 55,9 \\
\hline Internet (últ. 30 días) & 45,4 & 49,3 & 53,0 & 57,1 & 60,4 & 64,5 & 69,3 \\
\hline
\end{tabular}

Fonte: datos en porcentaxes e miles de persoas do universo poboacional do Estudio General de Medios. 
O fenómeno da prensa gratuíta foi un raio de sol que luciu mentres non chegou a crise da economía e da publicidade en 2008. Nese momento, as cabeceiras da prensa gratuíta comezaron a caer como follas secas en outono. No consumo xeral de prensa, a partir da eclosión da crise económica, destaca a caída dos xornais gratuítos en papel, ao mesmo tempo que a desaparición da maioría das súas cabeceiras, o estancamento da de información xeralista e a resistencia da deportiva.

Os xornais locais e de cobertura galega manteñen certa estabilidade pero non logran incrementar as súas cotas de audiencia mentres perden difusión no reconto da súa circulación a través da OJD. 0 certo é tamén que o número de lectores de prensa en Galicia descende a partir de 2012, fenómeno que tamén se aprecia no conxunto de España, pero a partir de 2013.

Cadro 14. Audiencia da prensa en Galicia

$\begin{array}{lllllllllll}2004 & 2005 & 2006 & 2007 & 2008 & 2009 & 2010 & 2011 & 2012 & 2013 & 2014\end{array}$

\begin{tabular}{|c|c|c|c|c|c|c|c|c|c|c|c|}
\hline Pob. España & 36408 & 37084 & 37439 & 37911 & 38261 & 39462 & 39435 & 39485 & 39449 & 39331 & 39681 \\
\hline Lectores España & 14980 & 15252 & 15660 & 15664 & 16102 & 15725 & 14994 & 14782 & 14223 & 12752 & 11809 \\
\hline Inf. xeral & 13534 & 13823 & 14211 & 14193 & 14547 & 13897 & 13127 & 12819 & 12353 & 10974 & 10146 \\
\hline Pob. Galicia & 2415 & 2422 & 2415 & 2422 & 2418 & 2447 & 2442 & 2436 & 2431 & 2414 & 2441 \\
\hline Lectores Galicia & 1158 & 1144 & 1259 & 1155 & 1194 & 1185 & 1132 & 1173 & 1152 & 1086 & 1068 \\
\hline Inf. xeral Galicia & 1114 & 1093 & 1210 & 1109 & 1132 & 1130 & 1062 & 1100 & 1095 & 1024 & 1011 \\
\hline Deportivos & 301 & 295 & 276 & 269 & 286 & 315 & 313 & 335 & 333 & 325 & 293 \\
\hline Gratuítos & 39 & 134 & 148 & 154 & 187 & 98 & 53 & 59 & 52 & & \\
\hline La Voz & 677 & 570 & 663 & 580 & 600 & 591 & 582 & 619 & 621 & 580 & 603 \\
\hline Faro Vigo & 301 & 290 & 290 & 267 & 274 & 273 & 268 & 267 & 285 & 259 & 279 \\
\hline Marca & 246 & 232 & 225 & 223 & 234 & 258 & 246 & 255 & 263 & 275 & 237 \\
\hline Que & & 116 & 137 & 126 & 143 & 48 & & & & & \\
\hline El País & 108 & 83 & 99 & 105 & 117 & 137 & 119 & 134 & 145 & 138 & 112 \\
\hline Progreso & 101 & 94 & 102 & 90 & 100 & 102 & 93 & 90 & 99 & 94 & 97 \\
\hline 20 Minutos & & & 98 & 101 & 148 & 83 & 46 & 55 & 45 & & \\
\hline Correo Gallego & 92 & 81 & 90 & 83 & 81 & 93 & 79 & 82 & 84 & 73 & 62 \\
\hline Mundo & 86 & 67 & 76 & 65 & 65 & 76 & 63 & 63 & 82 & 62 & 60 \\
\hline Región & 78 & 78 & 84 & 88 & 84 & 79 & 81 & 83 & 79 & 85 & 75 \\
\hline As & 57 & 64 & 58 & 62 & 83 & 79 & 83 & 87 & 90 & 93 & 86 \\
\hline Metro & 52 & 73 & 81 & & & & & & & & \\
\hline Diario Pontevedra & 46 & & & 50 & 38 & 45 & 44 & 43 & 47 & 46 & 45 \\
\hline Diario Ferrol & 44 & 30 & 29 & 28 & 33 & 24 & 31 & 26 & 25 & 31 & 27 \\
\hline Sport & 40 & 34 & 28 & 33 & 26 & 34 & 40 & 49 & 51 & 35 & 41 \\
\hline Opinión & 36 & 34 & 45 & & & & & & & 38 & 35 \\
\hline Deporte Campeón & 33 & 35 & 20 & & 13 & & & & & & 15 \\
\hline Ideal Gallego & 30 & 35 & 34 & 20 & 25 & 33 & 19 & 26 & 21 & 31 & 17 \\
\hline Atlántico & 29 & 25 & 18 & 18 & 18 & 13 & 18 & 17 & 16 & 14 & 18 \\
\hline$A B C$ & 20 & & 15 & & 18 & 19 & 23 & 25 & 23 & 18 & 17 \\
\hline SuperDepor & & & 13 & & & & & & & & \\
\hline Diar. Arousa & & & 13 & 15 & 14 & & & 16 & 17 & 12 & \\
\hline Mundo Deportivo & & & 13 & & & & 14 & 17 & 15 & 13 & 16 \\
\hline$A D N$ & & & & 64 & 80 & 48 & & & & & \\
\hline Luns Venres & & & & 30 & 35 & & 28 & 28 & 38 & & \\
\hline
\end{tabular}

Fonte: elaboración propia, con cifras en miles, a partir do Estudio General de Medios. 
Fronte á perda de audiencia da prensa, que se corresponde coa tendencia de descenso do seu consumo, aumenta a da radio en xeral, tanto a nivel de España como en Galicia. Pero ese incremento non está protagonizado pola radio xeralista, senón pola de carácter temático. Esta tendencia apunta a que os receptores dos medios tradicionais perden máis interese polos contidos de información xeral que polos de entretemento e especialización, especialmente os de ámbito deportivo.

Cadro 15. Audiencia da radio en Galicia

\begin{tabular}{lrrrrrrrrrrrrr} 
Emisoras & $\mathbf{2 0 0 2}$ & $\mathbf{2 0 0 3}$ & $\mathbf{2 0 0 4}$ & $\mathbf{2 0 0 5}$ & $\mathbf{2 0 0 6}$ & $\mathbf{2 0 0 7}$ & $\mathbf{2 0 0 8}$ & $\mathbf{2 0 0 9}$ & $\mathbf{2 0 1 0}$ & $\mathbf{2 0 1 1}$ & $\mathbf{2 0 1 2}$ & $\mathbf{2 0 1 3}$ & $\mathbf{2 0 1 4}$ \\
\hline Poboación & 2371 & 2401 & 2436 & 2422 & 2416 & 2422 & 2418 & 2447 & 2442 & 2436 & 2431 & 2414 & 2441 \\
\hline Audiencia & 1334 & 1428 & 1398 & 1345 & 1415 & 1413 & 1358 & 1410 & 1492 & 1502 & 1596 & 1521 & 1527 \\
\hline Xeralista & 813 & 859 & 890 & 809 & 807 & 788 & 749 & 784 & 770 & 799 & 863 & 802 & 780 \\
\hline Ser & 381 & 407 & 416 & 335 & 357 & 355 & 318 & 373 & 347 & 332 & 330 & 343 & 336 \\
\hline Onda Cero & 98 & 130 & 121 & 110 & 120 & 95 & 124 & 116 & 133 & 139 & 143 & 130 & 108 \\
\hline RNE 1 & 77 & & & 78 & 69 & 68 & 53 & 68 & 54 & 90 & 94 & 68 & 58 \\
\hline COPE & 135 & 124 & 147 & 161 & 138 & 142 & 137 & 121 & 103 & 126 & 148 & 135 & 167 \\
\hline R. Galega & 134 & 139 & 149 & 168 & 175 & 165 & 149 & 121 & 158 & 147 & 173 & 174 & 143 \\
\hline Radio Voz & & & 31 & 40 & 27 & 27 & 36 & 30 & 30 & 46 & 53 & 39 & 52 \\
\hline Temática & 547 & 602 & 587 & 606 & 662 & 716 & 629 & 717 & 840 & 797 & 876 & 847 & 862 \\
\hline C40 & 208 & 200 & 161 & 206 & 262 & 242 & 255 & 248 & 261 & 244 & 243 & 235 & 216 \\
\hline Dial & 150 & 136 & 116 & 129 & 110 & 123 & 97 & 92 & 96 & 102 & 118 & 104 & 109 \\
\hline C100 & 60 & 70 & 67 & 68 & 57 & 97 & 136 & 176 & 191 & 194 & 184 & 174 & 175 \\
\hline Kyss & 18 & 27 & 38 & 43 & 37 & 37 & 48 & 35 & 44 & 33 & 49 & 39 & 34 \\
\hline M80 & 56 & 64 & 88 & 77 & 77 & 78 & 50 & 50 & 51 & 45 & 46 & 45 & 35 \\
\hline Máxima & & 24 & 35 & 21 & 12 & 19 & 18 & 39 & 37 & 56 & 23 & 16 & 16 \\
\hline RNE 3 & 17 & & & & 34 & 22 & 22 & 15 & 28 & 31 & 29 & 26 & 33 \\
\hline Europa FM & 6 & 28 & 31 & 27 & 53 & 62 & 80 & 99 & 111 & 112 & 125 & 122 & 113 \\
\hline RG Música & & & & & & & & & 17 & 15 & 16 & 13 & 17 \\
\hline RNE5tn & 52 & & & 46 & 36 & 48 & 34 & 26 & 36 & 21 & 35 & 28 & 26 \\
\hline R. Marca & & 7 & 13 & 22 & 25 & 30 & 30 & 26 & 36 & 41 & 37 & 28 & 20 \\
\hline
\end{tabular}

Fonte: elaboración propia con cifras en miles de persoas, a partir do Estudio General de Medios.

Os cinco primeiros anos da segunda década do século xx son de grandes movementos no sector audiovisual pola repercusión da crise económica, os cambios no marco regulatorio e as transformacións tecnolóxicas. No ano 2013, a radio española rexistra os peores resultados económicos dos últimos dez anos (318 millóns de euros fronte a 391,6 millóns en 2010). Nese mesmo ano desaparece o cuarto operador nacional privado, prodúcese a adquisición pola Cope das emisores de ABC Punto Radio (grupo Vocento). As tres grandes cadeas (SER, Onda Cero-Uniprex e Cope) suman o 95,3 \% do negocio publicitario radiofónico. A concentración en televisión prodúcese pola absorción da publicidade de RTVE (a partir de 2010), a fusión de Telecinco e Cuatro (2011), Antena 3 e La Sexta (2012). Mediaset e A3Media pasan a controlar o $88 \%$ do mercado publicitario e o 57,7 da audiencia.

Neste último quinquenio prodúcese o primeiro apagamento analóxico (2010) e a segunda (2015) migración das emisións televisivas dixitais terrestres; a entrada en vigor da Lei xeral do audiovisual (7/2010); a aprobación da nova lei dos medios de comunicación audiovisual públicos de Galicia (9/2011); a supresión da publicidade en RTVE (Lei 8/2009) e o cambio no sistema de gobernanza desa corporación (2012); a flexibilización dos modos de xestión das radiotelevisións autonómicas (Lei 6/2012); a integración de Telecinco e Cuatro para formar 
Mediaset España; a absorción de La Sexta por Antena 3 en A3Media; a creación das plataformas de televisión online Mitele de Mediaset, A3 Player de A3M e Yomvi de Canal Plus; o peche de emisións de Canal 9 de Valencia (2013); a anulación polo Tribunal Supremo da concesión en 2010 dun múltiple completo de TDT a Antena 3, Telecinco, Sogecable, Veo7, Net TV e La Sexta; o peche de emisións (2014) de Net TV (Vocento) e Veo (Unedisa); e a adquisición de Ono por Vodafone (2013), de Canal Plus por Telefónica e do Grupo R por Euskaltel (en 2015). Os cambios legais, a crise económica e a concentración da publicidade repercuten de forma notoria nos orzamentos das radiotelevisións autonómicas.

Cadro 16. Orzamentos das RTVP autonómicas, 2007-2014

\begin{tabular}{|c|c|c|c|c|c|c|c|c|}
\hline \multirow[t]{2}{*}{ RTV de FORTA } & \multicolumn{2}{|c|}{2007} & \multicolumn{2}{|c|}{2008} & \multicolumn{2}{|c|}{2009} & \multicolumn{2}{|c|}{2010} \\
\hline & Orzam. & Subv. & Orzam. & Subv. & Orzam. & Subv. & Orzam. & Subv. \\
\hline Andalucía & 229,024 & 165,910 & 243,285 & 177,388 & 247,324 & 181,838 & 238,982 & 172,940 \\
\hline Cataluña & 393,888 & 217,205 & 378,409 & 206,079 & 383,805 & 226,255 & 390,566 & 256,070 \\
\hline Madrid & 157,053 & 85,293 & 161,724 & 89,579 & 143,284 & 89,564 & 150,792 & 111,341 \\
\hline Valencia & 276,819 & 188,912 & 309,146 & 219,217 & 238,561 & 150,506 & 182,280 & 141,452 \\
\hline Galicia & 122,953 & 97,139 & 131,790 & 103,808 & 134,183 & 106,999 & 138,049 & 102,168 \\
\hline P. Vasco & 183,327 & 121,324 & 173,733 & 139,072 & 183,723 & 148,920 & 176,292 & 149,060 \\
\hline Auton. históricas & 1363,06 & 875,78 & 1398,08 & 935,14 & 1330,88 & 904,08 & 1276,96 & 933,03 \\
\hline$\overline{\text { Canarias }}$ & 50,495 & 69,402 & 50,495 & 69,402 & 58,381 & 58,381 & 56,476 & 56,476 \\
\hline C. Mancha & 69,402 & 55,356 & 69,402 & 55,356 & 71,349 & 58,076 & 67,591 & 57,587 \\
\hline Murcia & 0 & 0 & 0 & 0 & 55,529 & 53,089 & 48,468 & 46,654 \\
\hline Aragón & 59,156 & 45,394 & 59,156 & 45,394 & 62,665 & 54,868 & 65,355 & 56,717 \\
\hline Baleares & 32,765 & 28,256 & 32,765 & 28,256 & 32,765 & 28,256 & 48,352 & 42,952 \\
\hline Outras autonomías & 231,81 & 202,4 & 231,81 & 202,4 & 300,68 & 256,67 & 306,24 & 264,37 \\
\hline Total & 1594,87 & 1078,18 & 1629,89 & 1137,54 & 1631,56 & 1160,75 & 1583,20 & 1197,4 \\
\hline \multirow[t]{2}{*}{ RTV de FORTA } & \multicolumn{2}{|c|}{2011} & \multicolumn{2}{|c|}{2012} & \multicolumn{2}{|c|}{2013} & \multicolumn{2}{|c|}{2014} \\
\hline & Orzam. & Subv. & Orzam. & Subv. & Orzam. & Subv. & Orzam. & Subv. \\
\hline Andalucía & 232,433 & 166,887 & 219,661 & 152,562 & 185,51 & 160 & 191,2 & 162,7 \\
\hline Cataluña & 367,898 & 241,390 & 310,248 & 202,475 & 378,55 & 260,77 & 293,05 & 226,6 \\
\hline Madrid & 147,114 & 105,364 & 147,114 & 105,364 & 99,15 & 84,15 & 85,37 & 74,87 \\
\hline$\overline{\text { Valencia }}$ & 165,644 & 124,110 & 138,003 & 99,246 & 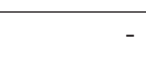 & - & - & \\
\hline Galicia & 121,550 & 101,147 & 117,164 & 99,147 & 107,9 & 94,07 & 103,6 & 90,32 \\
\hline P. Vasco & 171,654 & 140,762 & 167,106 & 130,964 & 175,15 & 139,01 & 135 & 112,13 \\
\hline Auton. históricas & 1206,29 & 879,66 & 1099,28 & 789,75 & 946,26 & 738 & 808,2 & 666,62 \\
\hline Canarias & 37,720 & 37,720 & 37 & 37 & 33,37 & 33,37 & 33,9 & 33,9 \\
\hline C. Mancha & 61,405 & 50,009 & 50,9 & 40,7 & 46,39 & 38,75 & 43,5 & 36,7 \\
\hline Murcia & 32,504 & 30,109 & - & - & - & - & - & - \\
\hline Aragón & 62,392 & 54,344 & 54,6 & 48 & 46,61 & 42,40 & 46,9 & 43 \\
\hline Baleares & 48,352 & 42,952 & 50,7 & 42,7 & 36,70 & 34 & 34 & 32,05 \\
\hline Asturias & & & 37,9 & 29,9 & 23,07 & 20,10 & 23,07 & 20,1 \\
\hline Estremadura & 32,22 & 31,05 & 27,3 & 26,6 & 24,8 & 23 & 24,8 & 23 \\
\hline Outras autonomías & 294,59 & 250,18 & 258,4 & 224,9 & 211 & 191,62 & 206,17 & 188,75 \\
\hline Total & 1501 & 1130 & 1357,4 & 1014,65 & 1157,2 & 929,62 & 1014,37 & 855,37 \\
\hline
\end{tabular}

Fonte: elaboración propia (cifras en millóns de euros) a partir dos orzamentos das RTVP autonómicas. 
Entre 2007 e 2014 os orzamentos das radiotelevisións autonómicas baixan un 36 \%, de 1594 a 1014 millóns. Neste período, a subvención directa das autonomías redúcese un $20 \%$, de 1078 a 855 millóns de euros. Os ingresos por publicidade nese período caen un $64 \%$ polo descenso da audiencia e a concentración do duopolio da televisión privada. Así, os aprovisionamentos das RTV autonómicas públicas baixan un 52 \%, de 586 a 278 millóns, e a contratación de servizos exteriores descende un 27 \% de 340 a 247 millóns de euros, entre 2007 e 2014. Ese impacto repercute negativamente na produción audiovisual privada, tamén na realizada en Galicia. A perda de recursos da CRTVG dana todo o audiovisual galego.

Cadro 17. Produción audiovisual galega

\begin{tabular}{|c|c|c|c|c|c|c|c|c|c|c|}
\hline \multirow{2}{*}{$\frac{\text { Empresa }}{\text { Anos }}$} & \multicolumn{5}{|c|}{ Ingresos } & \multicolumn{5}{|c|}{ Resultados } \\
\hline & 2013 & 2012 & 2011 & 2008 & 2007 & 2013 & 2012 & 2011 & 2008 & 2007 \\
\hline Abano & 270 & 122 & 408 & 34 & - & 7 & 7 & 16 & -5 & \\
\hline$\overline{\text { Adivina }}$ & 505 & 977 & 529 & 620 & 1223 & 5 & 2 & 5 & -32 & 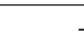 \\
\hline Arantia & 2324 & 2465 & 1713 & 533 & 888 & 89 & 359 & -130 & -564 & -158 \\
\hline Area 5.1 & 454 & 787 & 660 & 1022 & 784 & -68 & -26 & 1 & 2 & 137 \\
\hline Artemática & 431 & 177 & 140 & 128 & 29 & -4 & 0 & 0 & 25 & -27 \\
\hline Bambú & 18398 & 19377 & 22974 & 4393 & 68 & 26 & 136 & 194 & 10 & 12 \\
\hline Besteiro & 212 & 255 & 513 & 407 & 1027 & 13 & 12 & 45 & 14 & 384 \\
\hline Marcote & 904 & 808 & 796 & 1086 & 806 & 46 & 57 & 19 & 15 & 16 \\
\hline E. Cine & 32 & 72 & 128 & 161 & 159 & -28 & -58 & -27 & -9 & -10 \\
\hline Congo & 606 & 721 & 718 & 1597 & 1044 & 24 & 41 & 45 & 175 & 34 \\
\hline CTV & 5045 & 5365 & 6262 & 6865 & 7859 & 53 & -257 & 109 & 450 & 453 \\
\hline Enxebre & 38 & 89 & 87 & 217 & 148 & 12 & 24 & -32 & -42 & -8 \\
\hline Faro & 1963 & 2836 & 2362 & 5719 & 5261 & -258 & 50 & 54 & 116 & 62 \\
\hline Faro Lérez & 22 & 100 & 33 & 839 & 819 & -60 & 48 & 15 & 35 & 86 \\
\hline Ficción & 1397 & 1229 & 1338 & 963 & 1179 & 95 & 51 & 133 & 32 & 39 \\
\hline Filmanova I & 20 & 616 & 327 & 510 & 267 & 21 & -1025 & 202 & -431 & -711 \\
\hline Filmanova S & 1 & 49 & 46 & 113 & 321 & -4 & -11 & -14 & -18 & 32 \\
\hline Filmanova & 18 & 224 & 523 & 3169 & 4076 & -225 & -597 & 148 & -460 & 40 \\
\hline FilmaxAn. & - & - & - & 688 & 6608 & - & - & - & -1286 & 574 \\
\hline Formato & 455 & 528 & 603 & 938 & 802 & 5 & 4 & 11 & 4 & 23 \\
\hline Interdix & 123 & 187 & 222 & 168 & 196 & 1 & -21 & 1 & -38 & -22 \\
\hline Ilux & 639 & 290 & 185 & - & - & 5 & 1 & 3 & - & - \\
\hline Interacción & - & 109 & 272 & 363 & 447 & - & -1 & 5 & 8 & 9 \\
\hline Loroestudio & - & - & - & 362,67 & 447,31 & - & - & - & 7,62 & 9,44 \\
\hline Lugopress & - & 147 & 82 & 118 & 358 & - & -165 & -121 & 4 & 6 \\
\hline Milou & 485 & 2763 & 153 & 6391 & 1026 & 2 & 12 & 5 & -1057 & 4 \\
\hline Mondotropo & 191 & 450 & 382 & 772 & 514 & 4 & 5 & 0 & 0 & 0 \\
\hline Nos & 140 & 74 & 125 & 36 & 195 & -13 & 3 & 22 & -8 & 23 \\
\hline Raio Verde & 98 & 124 & 226 & 156 & 175 & 1 & 3 & 3 & -8 & 3 \\
\hline Openor & 354 & 343 & 384 & 275 & 238 & 13 & -32 & -62 & 66 & 30 \\
\hline Otiiplanet & 164 & 59 & 104 & 135 & - & 2 & 17 & -11 & 4 & 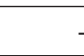 \\
\hline Pequerrecho & 49 & 57 & 16 & - & - & 0 & 0 & 2 & - & . \\
\hline Perro Verde & - & - & 62 & 174 & 138 & - & - & 1 & -29 & 4 \\
\hline
\end{tabular}




\begin{tabular}{lrrrrrrrrrr} 
Empresa & \multicolumn{9}{c}{ Ingresos } & \multicolumn{7}{c}{ Resultados } \\
\hline Anos & $\mathbf{2 0 1 3}$ & $\mathbf{2 0 1 2}$ & $\mathbf{2 0 1 1}$ & $\mathbf{2 0 0 8}$ & $\mathbf{2 0 0 7}$ & $\mathbf{2 0 1 3}$ & $\mathbf{2 0 1 2}$ & $\mathbf{2 0 1 1}$ & $\mathbf{2 0 0 8}$ & $\mathbf{2 0 0 7}$ \\
\hline Pórtico & - & 1493 & 1474 & 2549 & 2351 & - & 30 & 6 & 158 & 223 \\
\hline P. Vigo & 91 & 106 & 179 & 161 & 147 & -71 & -123 & -82 & -148 & -127 \\
\hline Saga & - & - & 338 & 324 & 333 & - & - & 0 & 0 & 0 \\
\hline Spica & 1810 & 3252 & 2342 & 3837 & 6407 & 50 & 71 & -11 & 69 & 282 \\
\hline Studio XXI & 599 & 644 & 992 & 1071 & 1077 & -48 & -24 & 105 & 145 & 99 \\
\hline Telecable C & 732 & 862 & 1728 & 2382 & 2276 & -285 & -202 & -128 & 58 & 5 \\
\hline Telemiño & 494 & 471 & 828 & 855 & 636 & 2 & -111 & 104 & 68 & 66 \\
\hline TV Siete & 930 & 653 & 685 & 1659 & 2043 & -30 & -112 & -38 & 113 & 126 \\
\hline Voz Audiov. & 3964 & 5396 & 6268 & 7882 & 10839 & 805 & 738 & 512 & 241 & 507 \\
\hline Canal Voz & 3964 & 1850 & 1606 & 1537 & 1644 & 62 & 111 & 95 & 182 & 195 \\
\hline Xamalú & 442 & 246 & 265 & 238 & 201 & 8 & 4 & 4 & 4 & 4 \\
\hline Cinemar & 175 & 197 & 265 & 112 & 15 & -88 & 22 & -28 & -9 & -73 \\
\hline Continental & - & - & - & 6771 & 6513 & - & - & - & 206 & 57 \\
\hline Sodinor & - & 485 & 671 & 848 & 1414 & - & -86 & -56 & 6 & 65 \\
\hline Vaca & 415 & 399 & 1179 & 148 & 406 & 48 & 80 & 876 & -27 & -35 \\
\hline Vía Láctea & 499 & 440 & 169 & 428 & 374 & 15 & 24 & 24 & 9 & 5 \\
\hline Zenit & 691 & 1235 & 1142 & 968 & 4776 & 10 & -51 & 1 & 46 & $-673,4$ \\
\hline ZircoZine & 830 & 1069 & 932 & 84 & - & 12 & -18 & 8 & -3 & -1 \\
\hline & & & & & & & & &
\end{tabular}

Fonte: datos de SABI (que recolle do Rexistro Mercantil). As cifras están en miles de euros e as de débeda en porcentaxes.

Os ingresos da produción audiovisual galega, tomando como referencia a relación das principais produtoras, sofren un impacto negativo superior ao $35 \%$ entre 2008 e 2013. E os ingresos desas empresas aínda caen moito máis nese período, ata un $85 \%$. Os efectos, como é obvio, repercuten no emprego, que sofre tamén un descenso do $25 \%$, e no incremento da débeda das empresas de produción audiovisual.

Cadro 18. Emprego e apancamento do audiovisual galego

\begin{tabular}{lrrrrrrrrrr} 
Empresa & \multicolumn{1}{c}{ Empregados declarados no R. Mercantil } & \multicolumn{5}{c}{ Porcentaxe de endebedamento } \\
\hline Anos & $\mathbf{2 0 1 3}$ & $\mathbf{2 0 1 2}$ & $\mathbf{2 0 1 1}$ & $\mathbf{2 0 0 8}$ & $\mathbf{2 0 0 7}$ & $\mathbf{2 0 1 3}$ & $\mathbf{2 0 1 2}$ & $\mathbf{2 0 1 1}$ & $\mathbf{2 0 0 8}$ & $\mathbf{2 0 0 7}$ \\
\hline Abano & 1 & 1 & 1 & 1 & - & 80,88 & 67,50 & 76,17 & 119,43 & - \\
\hline Adivina & - & - & - & - & - & 63,88 & 73,76 & 68,52 & 73,64 & 71,83 \\
\hline Arantia & 13 & 13 & 12 & 9 & 7 & 45,26 & 50,11 & 48,66 & 26,23 & 81,04 \\
\hline Area 5.1 & 9 & 9 & 11 & 15 & 21 & 32,69 & 35,47 & 29,95 & 39,43 & 44,49 \\
\hline Artemática & 2 & - & 3 & 3 & - & 78,99 & 80,04 & 76,38 & 95,91 & 87,55 \\
\hline Bambú & 140 & 116 & 185 & 43 & - & 93 & 94,76 & 97,67 & 97,10 & 43,34 \\
\hline Besteiro & 1 & 1 & 1 & 2 & 1 & 52,34 & 41,53 & 36,77 & 23,11 & 29,44 \\
\hline Marcote & 12 & 10 & 9 & 10 & 16 & 39,35 & 40,25 & 40,32 & 44,71 & 24,74 \\
\hline E. Cine & 1 & 2 & 1 & 2 & 6 & 155,11 & 138,28 & 105,11 & 171,95 & 164,96 \\
\hline Congo & 10 & 5 & 5 & 7 & 6 & 55,57 & 44,20 & 59,20 & 62,33 & 75,41 \\
\hline CTV & 101 & 101 & 89 & 75 & - & 48,23 & 45,98 & 47,15 & 47,36 & 55,87 \\
\hline Enxebre & 1 & 3 & 3 & 3 & 5 & 52,98 & 58,09 & 71,25 & 60,38 & 46,21 \\
\hline Faro & 43 & 55 & 44 & 98 & - & 72,89 & 69,09 & 71,73 & 81,43 & 86,29 \\
\hline
\end{tabular}




\begin{tabular}{|c|c|c|c|c|c|c|c|c|c|c|}
\hline \multirow{2}{*}{$\frac{\text { Empresa }}{\text { Anos }}$} & \multicolumn{5}{|c|}{ Empregados declarados no R. Mercantil } & \multicolumn{5}{|c|}{ Porcentaxe de endebedamento } \\
\hline & 2013 & 2012 & 2011 & 2008 & 2007 & 2013 & 2012 & 2011 & 2008 & 2007 \\
\hline Faro Lérez & 1 & 1 & 1 & 22 & - & 49,19 & 31,40 & 43,76 & 64,20 & 73,09 \\
\hline Ficción & 28 & 29 & 42 & 31 & 22 & 67,99 & 72,43 & 81,05 & 80,78 & 74,74 \\
\hline Filmanova I & 1 & 15 & 1 & - & - & 19,01 & 43,70 & 23,16 & 16,93 & 6,43 \\
\hline Filmanova S & 1 & 1 & 1 & - & - & 147,16 & 105,82 & 78,96 & 69,40 & 57,35 \\
\hline Filmanova & 3 & 3 & 13 & 31 & 49 & 101,88 & 90,00 & 63,24 & 91,74 & 82,81 \\
\hline FilmaxAn. & - & - & - & 4 & 13 & - & - & - & 70,10 & 85,45 \\
\hline Formato & 6 & 9 & 7 & 6 & 7 & 38,48 & 53,73 & 50,33 & 74,51 & 77,41 \\
\hline Interdix & 2 & 1 & 1 & 2 & 2 & 71,12 & 70,24 & 68,19 & 72,26 & 172,98 \\
\hline Ilux & 6 & 6 & 6 & - & - & 87,37 & 86,62 & 26,84 & - & \\
\hline Interacción & - & 6 & 7 & 11 & 10 & - & 59,64 & 66,32 & 71,51 & 71,16 \\
\hline Loroestudio & - & - & - & 4 & 3 & - & - & - & 61,85 & 10,84 \\
\hline Lugopress & - & 5 & 6 & 4 & 4 & - & 110,38 & 77,06 & 6,36 & 10,84 \\
\hline Milou & 1 & 2 & 2 & & & 19,69 & 25,39 & 34,87 & 44,32 & 6,85 \\
\hline Mondotropo & 3 & 4 & 5 & 4 & 4 & 90,60 & 96,04 & 98,39 & 98,03 & 98,03 \\
\hline Nos & 2 & 2 & 3 & - & - & 64,80 & 78,62 & 78,84 & 65,74 & 75,45 \\
\hline Raio Verde & 5 & 5 & - & 2 & 3 & 74,55 & 78,37 & 82,37 & 98,42 & 85,67 \\
\hline Openor & 2 & 2 & 3 & 1 & 1 & 135,63 & 132,73 & 23,64 & 47,09 & 29,75 \\
\hline Otiiplanet & 3 & 3 & 3 & 2 & - & 33,94 & 14,70 & 18,72 & 86,98 & 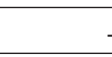 \\
\hline Pequerrecho & - & - & - & - & - & 78,87 & 77,05 & 55,28 & - & \\
\hline Perro Verde & - & - & 1 & 1 & 3 & - & - & 68,03 & 100,38 & 99,66 \\
\hline Pórtico & - & 31 & 31 & 46 & 47 & - & 43,41 & 48,09 & 60,08 & 66,76 \\
\hline P. Vigo & 4 & 5 & 6 & 3 & 4 & 120,20 & 109,96 & 92,88 & 219,65 & 198,95 \\
\hline Saga & - & - & 5 & 7 & 7 & - & - & 88,35 & 89,36 & 83,13 \\
\hline Spica & 21 & 24 & 25 & 25 & 24 & 30,23 & 48,79 & 48,73 & 56,64 & 75,33 \\
\hline Studio XXI & 13 & 13 & 15 & 24 & 24 & 25,41 & 16,48 & 17,48 & 12,89 & 15,85 \\
\hline Telecable C & 22 & 68 & 64 & 58 & 54 & 146,50 & 116,37 & 103,30 & 63,55 & 59,93 \\
\hline Telemiño & 16 & 24 & 25 & 25 & 19 & 20,48 & 19,19 & 26,09 & 46,93 & 52,91 \\
\hline TV Siete & 14 & 9 & 8 & 28 & 46 & 17,70 & 16,71 & 8,49 & 33,86 & 40,69 \\
\hline Voz Audiov. & 70 & 70 & 84 & 92 & 109 & 15,53 & 12,60 & 12,38 & 24,46 & 41,89 \\
\hline Canal Voz & 11 & 10 & 17 & 16 & 14 & 54,75 & 55,13 & 66,82 & 35,19 & 66,52 \\
\hline Xamalú & - & 2 & 1 & - & - & 36,17 & 61,40 & 62,60 & 94,73 & 79,06 \\
\hline Cinemar & 5 & 4 & 3 & - & - & 67,81 & 56,36 & 56,80 & 46,88 & 80,53 \\
\hline Continental & - & - & - & 35 & 40 & - & - & - & 94,72 & 95,97 \\
\hline Sodinor & - & 6 & 8 & 8 & - & - & 72,01 & 63,90 & 62,48 & 68,69 \\
\hline Vaca & 3 & 4 & 4 & 25 & 3 & 56,89 & 52,68 & 50,35 & 90,43 & 67,85 \\
\hline Vía Láctea & 2 & 3 & 9 & - & - & 69,98 & 62,35 & 92,27 & 87,92 & 90,41 \\
\hline Zenit & 9 & 18 & 11 & 10 & 12 & 80,93 & 84,65 & 79,55 & 81,84 & 87,62 \\
\hline ZircoZine & 3 & 3 & 1 & - & - & 41,94 & 56,00 & 46,88 & 100,30 & 38,77 \\
\hline
\end{tabular}

Fonte: elaboración a partir dos datos que as empresas entregan no Rexistro Mercantil procesados por SABI.

Unha tendencia aínda máis sobranceira rexístrase na actividade económica das principais editoriais galegas, que, no seu conxunto e nese mesmo período de 2008-2013, perden un $43 \%$ do seu negocio. Tamén destaca a perda 
de emprego e o seu incremento no nivel de apancamento, segundo os datos rexistrados polas editoras (todas elas pequenas e microempresas). Para reflectir a tendencia xeral, coma no caso das produtoras, recolléronse os datos dunha mostra diversa -aínda que non completa- de empresas dos sectores da produción de libros e audiovisual.

Cadro 19. Ingresos e resultados das editoriais galegas

\begin{tabular}{|c|c|c|c|c|c|c|c|c|c|c|}
\hline \multirow{2}{*}{$\frac{\text { Empresa }}{\text { Anos }}$} & \multicolumn{5}{|c|}{ Ingresos das contas segundo R. Mercantil } & \multicolumn{5}{|c|}{ Resultados das contas segundo R. Mercantil } \\
\hline & 2013 & 2012 & 2011 & 2008 & 2007 & 2013 & 2012 & 2011 & 2008 & 2007 \\
\hline Editora 2.0* & 155 & 144 & 296 & 340 & - & 2 & 6 & 5 & -10 & - \\
\hline Alvarellos & - & - & - & 19 & - & - & - & - & 1 & - \\
\hline Andavira & 186 & 193 & 236 & 252 & 242 & 0 & 1 & 14 & 2 & 3 \\
\hline Baía & 349 & 407 & 464 & 509 & 421 & 0 & 1 & 4 & 6 & 5 \\
\hline Biblos & 155 & 142 & 130 & 217 & 207 & -12 & -15 & -12 & -1 & -8 \\
\hline Difusora & 4 & 16 & 44 & 131 & 159 & 1 & 1 & 4 & 28 & 2 \\
\hline Linteo & 70 & 2558 & 1543 & 51 & 202 & -15 & -16 & -47 & -46 & -4 \\
\hline Do Castro & - & - & - & 95 & 170 & 0 & 0 & 0 & -173 & -165 \\
\hline Do Cumio & 364 & 317 & 439 & 554 & 369 & 9 & -59 & 21 & 36 & 10 \\
\hline Laiovento & 29 & 50 & 89 & 91 & 94 & -30 & -21 & -7 & -9 & 1 \\
\hline Lea & 2 & 12 & 18 & 52 & 66 & -14 & -16 & -16 & 1 & 3 \\
\hline Lóstrego & 7 & 16 & 17 & - & - & -19 & 6 & 4 & - & - \\
\hline Nigra Trea & 121 & 160 & 232 & 393 & 339 & -5 & -5 & -4 & 9 & 12 \\
\hline Obradoiro & 500 & 482 & 446 & 512 & 427 & 1 & 1 & 0 & 1 & 1 \\
\hline Danú & - & - & 150 & 23 & 40 & - & - & 2 & 0 & 0 \\
\hline Everest Gal. & 96 & 88 & 114 & 165 & 162 & -48 & -34 & -32 & 1 & 2 \\
\hline Galaxia & 1403 & 1505 & 1919 & 2164 & 1941 & -35 & -123 & 9 & 23 & 23 \\
\hline Galicia Media & 586 & 797 & 817 & 1197 & 2377 & -29 & 26 & 67 & 23 & 198 \\
\hline Netbiblo & - & 376 & 533 & 600 & 342 & - & 1 & 1 & 1 & 0 \\
\hline Novosvieiros & 60 & 169 & 451 & 293 & 620 & -69 & -39 & -1 & -84 & 12 \\
\hline Primerapersona** & & & & 35 & 59 & & & & -33 & -18 \\
\hline Toxosoutos & 263 & 315 & 369 & 531 & 494 & -29 & -3 & -5 & 2 & 1 \\
\hline Tris Tram & 1 & 2 & 5 & 19 & 20 & 0 & 0 & 0 & -2 & 0 \\
\hline Xerais & 1796 & 1807 & 2021 & 2921 & 2679 & -304 & -187 & -362 & -155 & -87 \\
\hline El Patito*** & - & - & 149 & 105 & - & - & - & 0 & -27 & - \\
\hline Galinova & 1070 & 1281 & 1376 & 1444 & 1212 & 448 & 512 & 493 & 622 & 475 \\
\hline Hércules & 1284 & 1328 & 2232 & 2875 & 3350 & -264 & -367 & 2 & 72 & 251 \\
\hline Ideaspropias & 574 & 718 & 1148 & 1633 & 1259 & 13 & 32 & 44 & 192 & 180 \\
\hline Kalandraka & 2000 & 1823 & 2084 & 2157 & 1884 & 65 & 25 & 34 & 22 & 42 \\
\hline Nova Galicia & 594 & 507 & 643 & 822 & 1099 & -7 & 3 & 1 & 31 & 32 \\
\hline QQO & 776 & 596 & 959 & 1100 & 691 & 60 & 8 & 51 & 32 & 38 \\
\hline Ouvirmos & 61 & 105 & 104 & 195 & 132 & 5 & 9 & 1 & 31 & 1 \\
\hline Sotelo & 99 & 117 & 106 & 308 & 350 & 4 & -7 & -13 & 8 & 14 \\
\hline Teófilo & 346 & 678 & 631 & 962 & 821 & -206 & 5 & 6 & 9 & 9 \\
\hline TresCtres $* * * *$ & - & - & - & 385 & 990 & - & - & - & 3 & 38 \\
\hline Xerme & 772 & 949 & 721 & 861 & 781 & 89 & -53 & 4 & -792 & 296 \\
\hline
\end{tabular}

Fonte: elaboración propia con cifras das contas presentadas no Rexistro Mercantil e procesadas por SABI. * Reverso Comunicación Cultura e Lingua SL ** Monllor y Gey editores SL *** Fausto Deseño Asociados **** 314 Euroediciones SL. 
A actividade destas empresas está directamente relacionada co investimento e gasto cultural. En 2013, segundo a enquisa de orzamentos familiares realizada polo Instituto Nacional de Estadística, o gasto cultural en España ascendeu a 12 261,7 millóns de euros, un 2,5 \% do destinado a bens e servizos en xeral. Os equipamentos audiovisuais e de Internet (43,9\%) representan o maior volume, seguido dos servizos culturais $(33,6 \%)$ e os libros e publicacións periódicas (15,8 \%). Galicia está por baixo da media de España en gasto cultural (arredor de 600 euros ao ano por fogar). Segundo a enquisa de hábitos e prácticas culturais, os máis frecuentes son escoitar música, ler e ir ao cine, con taxas do 84,4 \%, 58,7 \% e 49,1\%, respectivamente.

A produción editorial española aumentou en 2014 un 1,9 por cento con respecto ao ano anterior, ao pasar de 89130 en 2013 a 90802 libros. 0 aumento foi maior (un 3,7 \%) na publicación de libros en papel (68 378 en 2014 fronte a 65 942) mentres a edición noutros soportes (entre eles o dixital) descendeu nun 3,3 \% (22 424 títulos fronte a 23188 en 2013). A edición dixital representa o 25 \% da publicación editorial española, cun volume de actividade económica por riba dos 75 millóns de euros, aínda que de momento a súa facturación non pasa do $5 \%$ da actividade económica total do sector.

A edición en galego representa o 2,1 \% do total; en éuscaro, o 2 \%; en valenciano, o 1,4 \%; en catalán, o 9,9 \%, e en castelán, o 84,5\%. Durante 2014 editáronse en Galicia 2877 libros, nas provincias da Coruña (1421), Pontevedra (1321), Ourense (78) e Lugo (57). Esta última provincia foi a única que rexistrou un descenso $(-49,1 \%)$ no número de publicacións. O sector editorial en Galicia, como se aprecia nos seus resultados e apancamento, é feble e inestable.

Cadro 20. Emprego e endebedamento das editoriais galegas

\begin{tabular}{|c|c|c|c|c|c|c|c|c|c|c|}
\hline \multirow{2}{*}{$\frac{\text { Empresa }}{\text { Anos }}$} & \multicolumn{5}{|c|}{ Emprego segundo datos do Rexistro } & \multicolumn{5}{|c|}{ Mercantil Porcentaxes de endebedamento } \\
\hline & 2013 & 2012 & 2011 & 2008 & 2007 & 2013 & 2012 & 2011 & 2008 & 2007 \\
\hline Editora 2.0 & 2 & 4 & 8 & 10 & - & 92,53 & 95,27 & 99,86 & 100,22 & - \\
\hline Alvarellos & - & - & - & 2 & - & - & - & - & 7,88 & 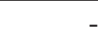 \\
\hline Andavira & 1 & 1 & 1 & 2 & - & 77,77 & 79,02 & 77,28 & 84,92 & 87,22 \\
\hline Baía & - & 3 & 3 & - & - & 91,24 & 83,32 & 81,44 & 85,39 & 84,96 \\
\hline Biblos & 3 & 2 & 2 & 2 & 2 & 41,60 & 31,03 & 30,87 & 29,81 & 27,85 \\
\hline$\overline{\text { Difusora }}$ & 1 & - & - & 1 & 2 & 16,30 & 14,25 & 29,29 & 63,23 & 93,49 \\
\hline Linteo & 3 & 2 & 2 & 2 & 1 & 0,22 & 3,58 & 0,26 & 1,52 & 65,78 \\
\hline Do Castro & - & - & - & 5 & 6 & 251,43 & 240,60 & 240,47 & 233,08 & 84,96 \\
\hline Do Cumio & 3 & 5 & 6 & 7 & 4 & 67,85 & 73,86 & 69,03 & 77,64 & 82,89 \\
\hline Laiovento & 1 & 1 & 1 & 1 & 1 & 57,70 & 28,76 & 15,91 & 77,52 & 72,55 \\
\hline Lea & - & 1 & 1 & 2 & 2 & 184,03 & 139,37 & 94,78 & 28,18 & 34,65 \\
\hline Lóstrego & - & - & - & - & - & 5,73 & 5,94 & 8,33 & - & \\
\hline Nigra Trea & 2 & 2 & 4 & 2 & 2 & 94,36 & 92,27 & 89,84 & 50,01 & 52,19 \\
\hline Obradoiro & 6 & 5 & 4 & 4 & 4 & 56,02 & 49,74 & 52,28 & 61,19 & 46,23 \\
\hline Danú & - & - & - & - & - & - & - & 72,98 & 71,80 & 65,68 \\
\hline Everest Gal. & 2 & 2 & 3 & 3 & 2 & 116,64 & 107,66 & 106,27 & 70,63 & 80,19 \\
\hline Galaxia & 16 & 19 & 19 & 17 & 18 & 49,10 & 39,62 & 38,87 & 51,40 & 52,65 \\
\hline Galicia Media & 4 & 3 & 4 & 3 & 4 & 12,18 & 21,05 & 14,02 & 32,96 & 39,86 \\
\hline Netbiblo & - & 1 & 1 & 2 & 2 & - & 97,13 & 97,84 & 97,80 & 97,84 \\
\hline Novosvieiros & 2 & - & 8 & 8 & 8 & 180,77 & 134,48 & 118,50 & 105,06 & 91,98 \\
\hline Primerapersona & - & - & - & 1 & 1 & - & - & - & 89,98 & 93,69 \\
\hline Toxosoutos & 4 & 3 & 4 & 5 & 5 & 100,09 & 95,25 & 94,96 & 94,38 & 94,90 \\
\hline
\end{tabular}




\begin{tabular}{lrrrrrrrrrr} 
Empresa & \multicolumn{1}{c}{ Emprego segundo datos do Rexistro } & \multicolumn{3}{c}{ Mercantil Porcentaxes de endebedamento } \\
\hline Anos & $\mathbf{2 0 1 3}$ & $\mathbf{2 0 1 2}$ & $\mathbf{2 0 1 1}$ & $\mathbf{2 0 0 8}$ & $\mathbf{2 0 0 7}$ & $\mathbf{2 0 1 3}$ & $\mathbf{2 0 1 2}$ & $\mathbf{2 0 1 1}$ & $\mathbf{2 0 0 8}$ & $\mathbf{2 0 0 7}$ \\
\hline Tris Tram & - & - & - & - & 1 & 84,22 & 83,87 & 83,40 & 77,79 & 69,60 \\
\hline Xerais & 14 & 14 & 14 & 16 & 14 & 91,40 & 88,01 & 94,33 & 58,58 & 50,29 \\
\hline El Patito & - & - & 2 & 3 & - & - & - & 68,82 & 107,58 & - \\
\hline Galinova & 4 & 3 & 3 & 4 & 3 & 12,62 & 17,32 & 17,87 & 21,42 & 24,26 \\
\hline Hércules & 22 & 27 & 29 & 36 & 37 & 11,66 & 10,05 & 8,90 & 16 & 13,85 \\
\hline Ideaspropias & 11 & 13 & 17 & - & - & 53,00 & 55,25 & 64,17 & 67,11 & 66,83 \\
\hline Kalandraka & 13 & 12 & 14 & 16 & 14 & 60,11 & 65,14 & 71,01 & 65,50 & 70,19 \\
\hline Nova Galicia & 6 & 7 & 12 & 13 & - & 35,11 & 28,63 & 31,32 & 24,88 & 30,65 \\
\hline OQO & 8 & 9 & 9 & 5 & 5 & 57,62 & 66,73 & 65,18 & 88,17 & 89,31 \\
\hline Ouvirmos & 1 & 2 & 2 & 2 & & 58,20 & 64,99 & 73,44 & 67,45 & 89,54 \\
\hline Sotelo & 2 & 2 & 2 & 2 & 2 & 98,08 & 99,04 & 97,82 & 97,33 & 98,49 \\
\hline Teófilo & 4 & 8 & 6 & 9 & 9 & 150,97 & 69,55 & 78,30 & 86,88 & 82,19 \\
\hline TresCtres & - & - & - & 3 & 1 & - & - & - & 48,62 & 42,43 \\
\hline Xerme & - & - & - & - & - & 83,67 & 113,44 & 98,63 & 156,31 & 67,36 \\
\hline
\end{tabular}

Fonte: elaboración propia con datos das contas do Rexistro Mercantil procesadas por SABI de Informa.es.

\section{CONCLUSIÓN}

Concluímos con intención futurista, pero non agoireira. A transición dixital avanza de forma incuestionable. Os medios de comunicación e as industrias culturais tradicionais teñen por diante unha década de retos inevitables. As proxeccións de cambio nos consumos dos produtos en papel, dos sistemas de difusión e modelos de negocio tradicionais son bastantes contundentes. A fragmentación das audiencias tradicionais e a obsolescencia das vellas tecnoloxías (posibilidade de desaparición da televisión dixital terrestre en 2025-30) poñen ás organizacións audiovisuais na carreira de dez anos para adaptarse á supervivencia en Internet. Iso é o que aventa o informe da nova Carta Real da BBC para o seu período de 2017-2027.

Esa supervivencia é máis vital para as radiotelevisións públicas porque as súas actuais estruturais están máis anquilosadas, a gobernanza máis burocratizada, o modelo de financiamento máis deteriorado e as políticas de regulamentación máis desorientadas. Porén, os medios de comunicación e servizos audiovisuais, tanto públicos como privados, son elementos esenciais de interacción social, simbólica e económica dos que as sociedades modernas non poden claudicar. Por iso, as políticas institucionais europeas, estatais e rexionais deben volver á reflexión dura sobre a importancia do seu valor estratéxico para os próximos anos.

$\mathrm{O}$ dilema do cambio nas organizacións tradicionais seguramente é o reto máis transcendente. Saber como, canto e cando cambiar é o gran dilema. Pero é un dilema que ten que ser dinámico e non estático. É o dilema da innovación e do talento da xestión. As organizacións tradicionais teñen grandes dificultades para acoplarse á innovación disruptiva (non poden abandonar os vellos modelos de negocio e adaptar os novos porque estes aínda non son rendibles e aqueles xa non producen o suficiente para a sustentabilidade) pero non poden abdicar da innovación adaptativa.

Mirando o noso territorio máis próximo, ese reto institucional e innovador aínda se presenta máis transcendente se observamos as perspectivas económicas e estratéxicas das distintas organizacións. A nova década dixital é aínda máis transcendente para a nosa cultura e identidade galegas. Trátase, pois, de poñer conciencia e visión de como pode ser e como debería ser a comunicación e as industrias culturais da Galicia de 2025. Un compromiso que abrangue as propias organizacións, as políticas institucionais e, tamén, a nosa sociedade no seu conxunto. 


\section{RECOÑECEMENTO DA INVESTIGACIÓN}

Os resultados deste artigo forman parte das actividades de investigación promovidas a través da Rede XESCOM (R2014/026 XESCOM), aprobada pola Consellería de Cultura, Educación e Ordenación Universitaria da Xunta de Galicia; das tarefas exploratorias do proxecto do Programa estatal de Fomento da Investigación Científica e Técnica de Excelencia, subprograma estatal de Xeración de Coñecemento do Ministerio de Economía e Competitividade de España sobre «Indicadores de gobernanza, financiamento, rendición de contas, innovación, calidade e servizo público das RTV europeas aplicables a España no contexto dixital» (Referencia CSO2015-66543-P); e do Programa Prometeo da Secretaría Nacional de Educación Superior, Ciencia, Tecnoloxía e Innovación (SENESCYT) de Ecuador, desenvolvido na Universidad Técnica Particular de Loja (UTPL) e na Pontificia Universidad Católica de Ibarra (PUCESI). 


\section{REFERENCIAS BIBLIOGRÁFICAS}

AETHA (2014): «Future use of the 470-694 MHz band. Report for Abertis, Arqiva, BBC, BNE, EBU and TDF», 31 de outubro. AlLE, Verna / Oliver SchwaBer (2011): Value Networks and the true nature of collaboration, ValuetNet Works, ed. (http://www. valuenetworksandcollaboration.com/).

BAuWEns, Michel (2015): Sauver le monde. Vers une économie post-capitaliste avec le peer-to-peer, París, Éditions Les Liens qui Libèrent.

Benghozı, Paul-Jean (2011): Télévision, l'ère du numérique, París, La Documentation Française.

Boyd, Danah M. / Nicole B. Eluıson (2007): «Social Network Sites: Definition, History, and Scholarship», Journal of ComputerMediated Communicaton, 13(1), 210-230.

Burnley, Richard (2015): Public Fundic Principles for Service Media, EBU (http://www3.ebu.ch/home).

BustamAnte, Enrique (1999): La television económica. Financiación, estrategias y mercados, Barcelona, Gedisa.

CALmard, Pierre (2015): L'homme à venir. Comment le numérique va nous transformer, París, Éditions Télémaque.

CAmpos-Freire, Francisco (2012): «Modelos de financiación de las televisiones públicas autonómicas», en Juan Carlos Miguel de Bustos / Miguel Ángel Casado del Río (coords.), Televisiones autonómicas. Evolución y crisis del modelo público de proximidad, Barcelona, Gedisa.

CAmpos Freire, Francisco. (coord.) (2011): El nuevo escenario mediático, Zamora / Sevilla, Comunicación Social.

CASTELLS, Manuel (2009): Comunicación y poder, Madrid, Alianza Editorial.

CELAYA, Javier et al. (2014): «Nuevos modelos de negocio en la era digital». Estudo elaborado por Dosdoce.com para CEDRO con motivo do lanzamento da plataforma Conlicencia.com (www.dosdoce.com).

Christensen, Clayton M. (1997): The Innovator's Dilemma: When New Technologies Cause Great Firms to Fail, Harvard Business Press.

Christensen, Clayton M. (2014): «Disruptive Innovation», en Mads Soegaard / Rikke Friis Dam (eds.), The Encyclopedia of Human-Computer Interaction, 2nd Ed., Aarhus, Denmark, The Interaction Design Foundation (https://www.interactiondesign.org/encyclopedia/disruptive innovation.html).

Christensen, Clayton M. / Joseph L. Bower (1995): "Disruptive Technologies: Catching the Wave», en Harvard Business Review (https://hbr.org/1995/01/disruptive-technologies-catching-the-wave).

CNMC (2014): «Informe económico de las telecomunicaciones y del sector audiovisual 2014» (www.cnmc.es).

DAvenport, Thomas H. / John C. Beck (2002): La economía de la atención: el nuevo valor de los negocios, Barcelona, Paidós.

DCMS (2015): «BBC Charter Review Public Consultation 16 july-8 october 2015», Department for Culture, Media and Sport (https://www.gov.uk/government/organisations/department-for-culture-media-sport)

DigitAl FutURE (2014): The 2014 Digital Future Report. Surveying The Digital Future. Year Twelve, Annenberg School Center for the Digital Future, University of Southern California. Jeffrey I. Cole director World Internet Project, Michael Suman, Phoebe.

DiRECTIVAS UE: 89/552/CEE de la TV Sin Fronteras, 2007/65/CE de Servicios de Comunicación Audiovisual e 2010/13/UE de Medios Audiovisuales (www.europa.eu).

Donders, Karen (2011): Public service media and policy in Europe, Londres, Palgrave Macmillan.

Donders, Karen / Hallvard Moe (2011): «Exporting the Public Value Test: The Regulation of Public Broadcasters' New Media Services across Europe», Göteborg, Nordicom.

Doyle, Gillian (2012): «Economía audiovisual: los mercados audiovisuales en la Unión Europea», Quaderns del CAC, 38, vol. $\mathrm{XV}(1), 15-24$.

EBU (2012): «EBU Viewpoint PSM Funding», EBU-UER, European Broadcasting Union (EBU) (http://www3.ebu.ch/home).

ERICSON (2015): «TV and Media 2015. The empowered TV and Media consumer's influence» (http://www.ericsson.com/res/ docs/2015/consumerlab/ericsson-consumerlab-tv-media-2015.pdf).

Fernández Lombao, Tania / Francisco Campos FreiRe (2013): «La Responsabilidad Social Corporativa en las radiotelevisiones públicas en Europa», Cuadernos Info, Chile, 33, 145-157. DOI 107764/cdi. 33.530.

FINE, Charles H. (2000): El nuevo ciclo empresarial. Ventajas competitivas en la era de la velocidad, Barcelona, Paidós.

FLICHY, Pierre (1980): Les industries de l'imaginaire: pour une anályse économique des media, París, INA.

Fuchs, Christian (2014): "Medios sociales y esfera pública», Telos, 98, xuño-setembro.

GoyAnEs, Manuel (2013): «Estrategias y modelos de negocio: Aclaración de conceptos y terminología de la prensa en Internet», Estudios sobre el Mensaje Periodístico, 1, 419-431. 
Hallin, Daniel C. / Paolo Mancini (2008): Sistemas mediáticos comparados. Tres modelos de relación entre los medios de comunicación y la política, Barcelona, Editorial Hacer.

IOSIFIDIS, Petros (2010): «Servicio público de televisión en Europa», Infoamérica, Málaga (www.infoamerica.org/icr/n03-04/ iosifidis.pdf).

IoSIFIDIS, Petros (2011): «Growing pains? The transition to digital TV in Europe», European Journal of Communication, 26(1), 3-17.

Jenkins, Henry (2006): Convergence Culture: Where Old and New Media Collide, Nova York, New York University Press.

Jost, Françols (2011): «Place du produit télévisuel dans I'espace public et I'espace social», en J.-Ch. Paracuellos / P.-J. Benghozi, Télévision, I'ère du numérique, París, La Documentation Française.

KEvin, Deirdre (2015): Snapshot: Regional and local television in Spain, European Audiovisual Observatory.

KEvin, Deirdre (2015): Snapshot: Regional and local television in United Kingdom, European Audiovisual Observatory.

LANGE, André (2011): "Convergence et diversité des systèmes européens», en J.-Ch. Paracuellos / P.-J. Benghozi, Télévision, I'ère du numérique, París, La Documentation Française

LÉvY, Pierre (2007): Cibercultura. La cultura de la sociedad digital, Barcelona, Anthropos.

LloRÉns MaLuquer, Carlos (2008): «Las políticas de Internet de RTVE y la BBC: la redefinición e implementación del servicio público en los nuevos medios», EPTIC, Revista de Economía Política de las Tecnologías de la Información y Comunicación, X(2) (www.eptic.com.br) [última consulta: 20/9/2914].

LóPez CEPEDA, Ana María (2010): Órganos de control e xestión da Radiotelevisión pública estatal e autonómica en España. A cualificación e profesionalidade de Directores xerais, Consellos de Administración, Comisións de Control Parlamentario e Consellos Audiovisuais, tese de doutoramento, Facultade de Ciencias da Comunicación, Universidade de Santiago de Compostela.

López García, Xosé (2010): La metamorfosis del periodismo. Historia de lo que permanece y de lo que cambia en el ciberperiodismo del tercer milenio, Zamora / Sevilla, Comunicación Social.

Manovich, Lev (2005): El lenguaje de los nuevos medios de comunicación: la imagen en la era digital, Barcelona, Paidós.

Manovich, Lev (2008): Software takes command, Nova York, Georgetown University (http://faculty.georgetown.edu/irvinem/ theory/Manovich-Software-Takes-Command-ebook-2008-excerpt.pdf).

Manovich, Lev (2013): Software Takes Command (International Texts in Critical Media Aesthetics), Nova York, Blomsbury.

Marzal Felicl, Javier / Jessica IzQuierdo CAstillo / Andreu CASERo Ripollés (eds.) (2015): La crisis de la televisión pública. El caso de RTVV y los retos de la nueva gobernanza, Barcelona, Aldea Global.

MatTelart, Armand (2007): Historia de la sociedad de la información, Barcelona, Paidós.

MECD (2015): «Anuario de Estadísticas Culturales 2014 | Principales resultados», Ministerio de Educación, Cultura e Deporte (http://www.mecd.gob.es/cultura-mecd/areas-cultura/libro.html).

Negroponte, Nicholas (1995): Ser digital, Bos Aires, Atlántida.

Noguera Vivo, José Manuel (2012): Redes y periodismo, Barcelona, UOC.

Noguera Vivo, José Manuel (2014): Economía de la participación, Madrid, Fundación EOI.

NYT (2014): Innovation, The New York Times (http://www.nytinnovation.com/).

OBS (2014): Yearbook 2014. Television, cinema, video on-demand audiovisual services-the pan-European picture, European Audiovisual Observatory, pdf.

Osterwalder, Alexander (2004): The Business Model Ontology. A proposition in a design science approach, Laussanne, Université de Lausanne, tese de doutoramento.

Osterwalder, Alexander / Yves Pigneur / Christopher L. Tuccl (2005): «Clarifying Business Models: origins, present, and future of the concept», Communications of the Association for Information Systems, 15.

PICARD, Robert G. (2014): «Twilight or New Dawn of Journalism. Evidence from the changing news ecosystem», Journalism Studies, 15, 5.

PICARD, Robert G. / Paolo SICILIANI (eds.) (2013): Report. Is there Still a Place for Public Service Television? Effects of the Changing Economics of Broadcasting, Oxford, Reuters Institute for the Study of Journalism / BBC Trust / Universidade de Oxford.

Prado, Emili (2015): «La televisión pública», en Javier Marzal Felici / Jessica Izquierdo Castillo / Andreu Casero Ripollés (eds.), La crisis de la televisión pública. El caso de RTVV y los retos de la nueva gobernanza, Barcelona, Aldea Global.

PuppIS, Manuel (2010): «Media Governance: A New Concept for the Analysis of Media Policy and Regulation», Communication, Culture \& Critique, 3(2), 134-149. 
PuPPIS, Manuel (2012): «Between independence and autonomous adaptation: The Europeanization of television regulation in non-EU member states», Communications. European Journal of Communication Research, 37(4), 393-416. DOI: 10.1515/ commun-2012-0022.

Puppis, Manuel / Martino Maggetti / Fabrizio Gilardi / Jan Biela / Yannis Papadopoulos (2014): «The Political Communication of Independent Regulatory Agencies», Swiss Political Science Review, 20(3), 388-400.

PWC (2015): «Global Entertainment and Media Outlook 2015-2019» (www.pwc.com).

Report Reuters Digital (2014): «News Report 2014 Tracking The Future of News», Reuters Institute Digital, Reuters Institute for the Study of Journalism.

Rushkoff, Douglas (2014): «The next Big think. On the economy likes», Rhapsody Magazine (http://www.rushkoff.com/storage/ Rhapsody \%20magazine \%20_ \%20Apr \%202014 \%20 \%20Ink \%20eMagazines.pdf).

SABI (2014): Base de datos de Análisis de Balances Ibéricos de Empresas (http://sabi.bvdep.com/ip////).

WAN (2014): «World Trends Database», Asociación Mundial de Diarios, WAN-IFRA (www.wan-ifra.org).

WNMN (2014): «Global Digital Media Trendbooks 2014», World News Media Network (www.wnmn.org). 